\title{
Mesenchymal stem cells as a double-edged sword in tumor growth: focusing on MSC-derived cytokines
}

\author{
Wenqing Liang ${ }^{1^{*}+}\left(\mathbb{0}\right.$, Xiaozhen Chen $^{2+}$, Songou Zhang ${ }^{2 \dagger}$, Jian Fang ${ }^{2}$, Meikai Chen ${ }^{3}$, Yifan $\mathrm{Xu}^{3}$ \\ and Xuerong Chen ${ }^{3}$
}

*Correspondence:

drliangwenqing@yeah.net

tWenqing Liang, Xiaozhen

Chen, and Songou Zhang

contributed equally to this work

${ }^{1}$ Department

of Orthopaedics, Zhoushan

Hospital of Traditional

Chinese Medicine Affiliated

to Zhejiang Chinese Medical

University, 355 Xinqiao

Road, Dinghai District,

Zhoushan 316000, Zhejiang,

People's Republic of China

Full list of author information

is available at the end of the article

\begin{abstract}
Mesenchymal stem cells (MSCs) show homing capacity towards tumor sites. Numerous reports indicate that they are involved in multiple tumor-promoting processes through several mechanisms, including immunosuppression; stimulation of angiogenesis; transition to cancer-associated fibroblasts; inhibition of cancer cell apoptosis; induction of epithelial-mesenchymal transition (EMT); and increase metastasis and chemoresistance. However, other studies have shown that MSCs suppress tumor growth by suppressing angiogenesis, incrementing inflammatory infiltration, apoptosis and cell cycle arrest, and inhibiting the AKT and Wnt signaling pathways. In this review, we discuss the supportive and suppressive impacts of MSCs on tumor progression and metastasis. We also discuss MSC-based therapeutic strategies for cancer based on their potential for homing to tumor sites.
\end{abstract}

Keywords: Angiogenesis, Cancer-associated fibroblasts, Immunosuppression, Metastasis, Mesenchymal stem cells

\section{Introduction}

MSCs (mesenchymal stem cells) are multipotent stem cells with high self-renewal and differentiation potential capabilities. They are a promising source for cell therapy-based regenerative medicine. The MSCs' therapeutic features are associated with their potentials for trans-differentiation, trophic factor secretion and immunomodulation [1-3]. They already have broad applications in the treatment of degenerative diseases, including retinal degenerative disease [4, 5], multiple sclerosis [6], Alzheimer's disease [7], Parkinson's disease [8,9], degenerative disc disease [10], amyotrophic lateral sclerosis [11], type 1 diabetes mellitus [12] and myocardial infarction [13].

MSCs differentiate into multiple mesenchymal cell lineages, including adipocytes, osteocytes, chondrocytes, pericytes and fibroblasts [14-19]. They can also transdifferentiate into ectodermal (neuronal) and endodermal (epithelial) lineages, and into hepatocytes under certain in vitro culture conditions [20-22]. MSCs can also participate in supporting tissue architecture and controlling inflammation [23-25].

(C) The Author(s) 2021. Open Access This article is licensed under a Creative Commons Attribution 4.0 International License, which permits use, sharing, adaptation, distribution and reproduction in any medium or format, as long as you give appropriate credit to the original author(s) and the source, provide a link to the Creative Commons licence, and indicate if changes were made. The images or other third party material in this article are included in the article's Creative Commons licence, unless indicated otherwise in a credit line to the material. If material is not included in the article's Creative Commons licence and your intended use is not permitted by statutory regulation or exceeds the permitted use, you will need to obtain permission directly from the copyright holder. To view a copy of this licence, visit http:// creativecommons.org/licenses/by/4.0/. 
In general, MSCs support tissue integrity as the crucial regulators of tissue homeostasis. In addition to their normal distribution in particular organs, they accumulate in damaged tissues, contributing to tissue regeneration and wound healing [24, 26, 27]. In response to tissue injury, they are mobilized from their niches upon suitable signals and recruited into tissues to participate in tissue regeneration and remodeling [28, 29]. Certain factors and conditions, including TGF $\beta$ [30], G-CSF [31] and exercise [32], can increase their mobilization and homing to peripheral blood and injured sites.

Despite intensive investigation over the years, the in vitro classification of MSCs is still unclear. Morphological observation of cultures shows a heterogeneous cell population comprising various subsets of fibroblast-like cells, round cells or flattened cells [33-35]. The differentiation and functional features of each cell subset have not been completely identified, but the minimal criteria suggested by the ISCT (International Society for Cellular Therapy) have been applied to define them. The defining characteristics are: plasticadherent properties in standard culture circumstances; over 95\% of cells in a considered population expressing CD73 and CD105, with no expression (less than $2 \%$ positive) of CD34, CD45, CD14 or CD79 $\alpha, \mathrm{CD} 11 b, \mathrm{bD} 19$ as well as HLA-DR markers; differentiation into adipocytes, chondroblasts and osteoblasts under standard circumstances in vitro [36]. Studies indicate that MSC populations' heterogeneity probably explains their capability of differentiating into various distinct cell types [37-39].

MSCs secrete soluble factors and mediators, such as indoleamine 2,3-dioxygenase (IDO), nitric oxide (NO), prostaglandin (PGE2), IL-10, IL-6 and HLA-G (human leukocyte antigen). It has been determined that these mediators regulate the function and proliferation of various immune cells and the stimulation of TREG (regulatory T) cells directly or indirectly through the creation of immature dendritic cells (DCs) [40]. Along with the release of immunomodulators, MSCs can directly inhibit immune cell activation through cell-to-cell interaction. Direct contact between MSCs and T cells leads to inhibition of cell proliferation through induction of effector $\mathrm{T}$ cell apoptosis as the programmed death-1 (PD-1) molecules interact with its PD-L1 and PD-L2 ligands. Moreover, $\mathrm{T}$ cell anergy can be induced by MSCs through inhibition of the CD86 and CD80 expression in antigen-presenting cells [41-43].

MSCs also secrete various modulatory factors that are able to regulate inflammation, angiogenesis, cell death, tissue regeneration and fibrosis [44]. It was reported that they secrete trophic parameters that can increase cell survival, cell proliferation and tissue angiogenesis [45-47]. Furthermore, they are able to migrate toward injured tissues along chemoattractant gradients within the peripheral blood and stromal extracellular matrix (ECM) [48]. In injured tissues, local factors, such as cytokine milieu, hypoxia and Tolllike receptor ligands, stimulate MSCs, promoting the creation of growth factors in large quantity to drive tissue regeneration $[49,50]$.

On the other hand, studies have shown that MSCs can increase or decrease tumorigenesis under various conditions [51,52]. Within its microenvironment, the tumor tries to prevent identification by the immune system, which establishes a stable inflammatory state by secreting inflammatory mediators [53]. There is an increasing focus on the interaction between cancer cells, normal cells and the matrix in the tumor microenvironment, because these interactions contribute to the milestones of cancer development, such as angiogenesis, immunomodulation, metastasis and invasion, as well as apoptotic 
resistance [54, 55]. In some research, it was indicated that MSCs travel to the cancer microenvironment, where they support the creation of the tumor vascular system and overwhelm immune reactions, thus modulating the tumor response to anti-tumor therapy [56-60]. MSC survival rates were also found to increase under oxidative, heat shock, hypoxic and nutrient-deprived conditions, which can occur in solid tumors, by inducing the expression of cytoprotective genes and promoting MSC potency through improving production and secretion of compensating factors [61-64]. Indeed, MSCs utilize an autophagic metabolism to provide the required nutrients for long-term survival and by secretion of survival factors helps to increase the survival rate of MSCs and the surrounding cells of them [65]. Contrary to their tumor-promoting capabilities, MSCs are also able to restrict tumor growth by suppressing angiogenesis, inhibiting proliferationrelated signaling paths like PI3K, Wnt and AKT, and inhibiting cell cycle progression [66-71].

This review focuses on the supportive and suppressive impacts of MSCs on tumor progression and metastasis. We also discuss MSC-based therapeutic strategies for cancer, which are based on their potential for homing to tumor sites.

\section{The supportive effects of mesenchymal stem cells on tumor growth}

MSCs display a robust tropism to damaged tissue and wounds, where they promote regenerative activities [50,72]. In general, tumors, which can be compared to chronic non-healing wounds, also recruit MSCs to supporting their metastasis and growth [7375]. The mechanisms of MSC homing is likely due to receptors and chemokines promoting the transfer of other accessory cells to the tumors. These would include growth factors (PDGF, SCF, HGF, IGF-1E and GF) [76, 77]; angiogenic factors ( $\beta F G F, H I F 1 \alpha$ and VEGF) [78, 79]; chemokines (CCL5, CCL2, CXCL12 and CCL22) [76, 80]; cytokines and inflammatory factors (TGF $\beta$, TNF $\alpha$, IL-8 and IL-1 $\beta$ ) [81-84]. MSC recruitment to various types of tumor may crucially contribute to the tumor fate. The capability of MSCs to promote metastasis and tumor growth was shown in a breast tumor model in mice [85]. Similar findings have been reported for MSCs co-implanted with cancer cells [86-88]. Moreover, tumor formation is not supported by findings for allogeneic mice with transplanted B16 melanoma cells but no concomitant MSC co-injection [89]. The supportive mechanisms of mesenchymal stem cell on tumor growth are presented in Table 1.

\section{Suppression of the immune response in tumor microenvironments}

MSCs have robust immunosuppressive features that support the tumor cells to escape from immune surveillance (Fig. 1). MSCs can be activated within tumor microenvironments by the pro-inflammatory cytokines TNF- $\alpha$, IFN- $\gamma$ or IL- $1 \beta$ [82, 90-92], which are secreted by macrophages and tumor cells. Extensive immunosuppression is then induced, mainly by MSCs through the secretion of mediators and soluble factors, such as indoleamine 2,3-dioxygenase (IDO), TGF $\beta, T N F \alpha$, IFN $\gamma$, prostaglandin E2 (PGE2), NO, HLA-G, HGF, IL-1 $\beta$, IL-1 $\alpha$, IL- 4 and IL-6, and through their interactions with different types of immune cell, including B cells, T cells, dendritic cells, NK cells and macrophages [92-94]. Considering the expression of both HLA-G and IDO in the placenta, MSCs probably contribute to immune tolerance during pregnancy. These mediators reduce effector $\mathrm{T}$ cell proliferation, IgG secretion, B cell proliferation, DC maturation, 
Table 1 The effect of MSC-derived mediators on tumor growth

\begin{tabular}{|c|c|c|c|}
\hline $\begin{array}{l}\text { Pro-tumorigenic activity } \\
\text { of MSCs }\end{array}$ & Factors secreted by & $\begin{array}{l}\text { Effects of secreted } \\
\text { factors and mediators }\end{array}$ & References \\
\hline Immunosuppression & $\begin{array}{l}\text { MSCs: TGFß, IFNY, TNFa, } \\
\text { PGE2, CCL2, galectin-9, } \\
\text { HGF, CTLA-4, soluble } \\
\text { PD-L1 and PD-L2, NO, } \\
\text { HLA-G, IDO, IL-1a, IL-1 } \beta \text {, } \\
\text { IL-4 and IL-6 }\end{array}$ & $\begin{array}{l}\text { Immune tolerance } \\
\text { T, B, NK, Dendritic cell } \\
\text { inhibition } \\
\text { Promotion of Treg cells } \\
\text { proliferation } \\
\text { Recruitment of MDSCs } \\
\text { Apoptosis of lymphocytes } \\
\text { and neutrophils } \\
\text { Reduction of CD80/CD86 } \\
\text { expression on APCs }\end{array}$ & {$[40,92-96,103-105,109]$} \\
\hline Promotion of angiogenesis & $\begin{array}{l}\text { VEGF, FGF-2, } \beta F G F, \text { PDGF, } \\
\text { IL-6, IL-8, TGF } \beta \text { and } \\
\text { angiopoietin-1 }\end{array}$ & $\begin{array}{l}\text { Promotion of tumor } \\
\text { angiogenesis } \\
\text { Transformation into } \\
\text { smooth muscle cells and } \\
\text { pericytes } \\
\text { Mobilization and recruit- } \\
\text { ment of MSCs into } \\
\text { neovascularization sites } \\
\text { Tumor vessel formation } \\
\text { Inducing expressing of } \\
\text { junctional proteins }\end{array}$ & $\begin{array}{l}{[51,88,123,124,127-129,} \\
\quad 135-137]\end{array}$ \\
\hline $\begin{array}{l}\text { Transition of mesenchymal } \\
\text { stem cells to cancer- } \\
\text { associated fibroblasts }\end{array}$ & $\begin{array}{l}\text { CAFs: a-SMA, tenascin-C, } \\
\text { fibroblast surface protein } \\
\text { (FSP), CCL5, CXCL12, IL-6, } \\
\text { IL-4, IL-8, TNF, TGFB, VEGF }\end{array}$ & $\begin{array}{l}\text { Stimulation of tumor } \\
\text { growth } \\
\text { Promotion of tumor } \\
\text { vascularization }\end{array}$ & {$[88,142-144]$} \\
\hline $\begin{array}{l}\text { Epithelial-mesenchymal } \\
\text { transition (EMT) }\end{array}$ & $\begin{array}{l}\text { HGF, EGF, PDGF, leptin and } \\
\text { TGF } \beta\end{array}$ & $\begin{array}{l}\text { Induction of transcrip- } \\
\text { tional regulators: snail, } \\
\text { slug, twist, Zeb1 } \\
\text { Increasing the metastatic } \\
\text { capacity } \\
\text { Inducing EMT and pro- } \\
\text { moting a cancer stem } \\
\text { cell (CSC) phenotype }\end{array}$ & {$[152-154,157,158]$} \\
\hline $\begin{array}{l}\text { Correlation of MSCs with } \\
\text { cancer stem cells }\end{array}$ & $\begin{array}{l}\text { BMP, IL-6, IL-8, CXCL6, and } \\
\text { CXCL5 }\end{array}$ & $\begin{array}{l}\text { Proliferation of CSCs and } \\
\text { increasing their invasive } \\
\text { properties }\end{array}$ & {$[90,164,165]$} \\
\hline $\begin{array}{l}\text { Promotion of tumor } \\
\text { metastasis }\end{array}$ & $\begin{array}{l}\text { Lysyl oxidase (LOX), TGF }, \\
\text { FGF, HGF, EGF, CCL5, } \\
\text { CXCL5, CXCL1, CXCL7 } \\
\text { and CXCL8 }\end{array}$ & $\begin{array}{l}\text { Promotion of tumor cell } \\
\text { migration } \\
\text { Extracellular matrix modu- } \\
\text { lation } \\
\text { Enhancing tumor cell } \\
\text { invasiveness and induc- } \\
\text { ing EMT } \\
\text { Activation of matrix metal- } \\
\text { loproteinase } 9 \text { (MMP-9) } \\
\text { Overexpression of rho- } \\
\text { associated kinase }\end{array}$ & {$[59,75,167,171,173-175]$} \\
\hline $\begin{array}{l}\text { Inhibition of apoptosis in } \\
\text { cancer cells }\end{array}$ & $\begin{array}{l}\text { VEGF, FGF-2, PDGF, HGF, } \\
\text { BDNF, SDF-1a, IGF-1 and } \\
\text { IGF-2, TGF- } \beta \text { and IGFBP-2 }\end{array}$ & $\begin{array}{l}\text { Inhibition of tumor cell } \\
\text { apoptosis and promo- } \\
\text { tion of tumor prolifera- } \\
\text { tion } \\
\text { Stimulation of the angio- } \\
\text { genesis }\end{array}$ & {$[52,184-188]$} \\
\hline $\begin{array}{l}\text { Promotion of drug resist- } \\
\text { ance }\end{array}$ & $\begin{array}{l}\text { CXCL12, EGF, IGF, IL-6, IL-7, } \\
\text { IL-8 and PGE-2 }\end{array}$ & $\begin{array}{l}\text { Reducing caspase } 3 \\
\text { activity } \\
\text { Inhibition of apoptosis fol- } \\
\text { lowing cytotoxic therapy } \\
\text { Promotion of the CSCs } \\
\text { formation }\end{array}$ & {$[91,133,164,196,198]$} \\
\hline
\end{tabular}




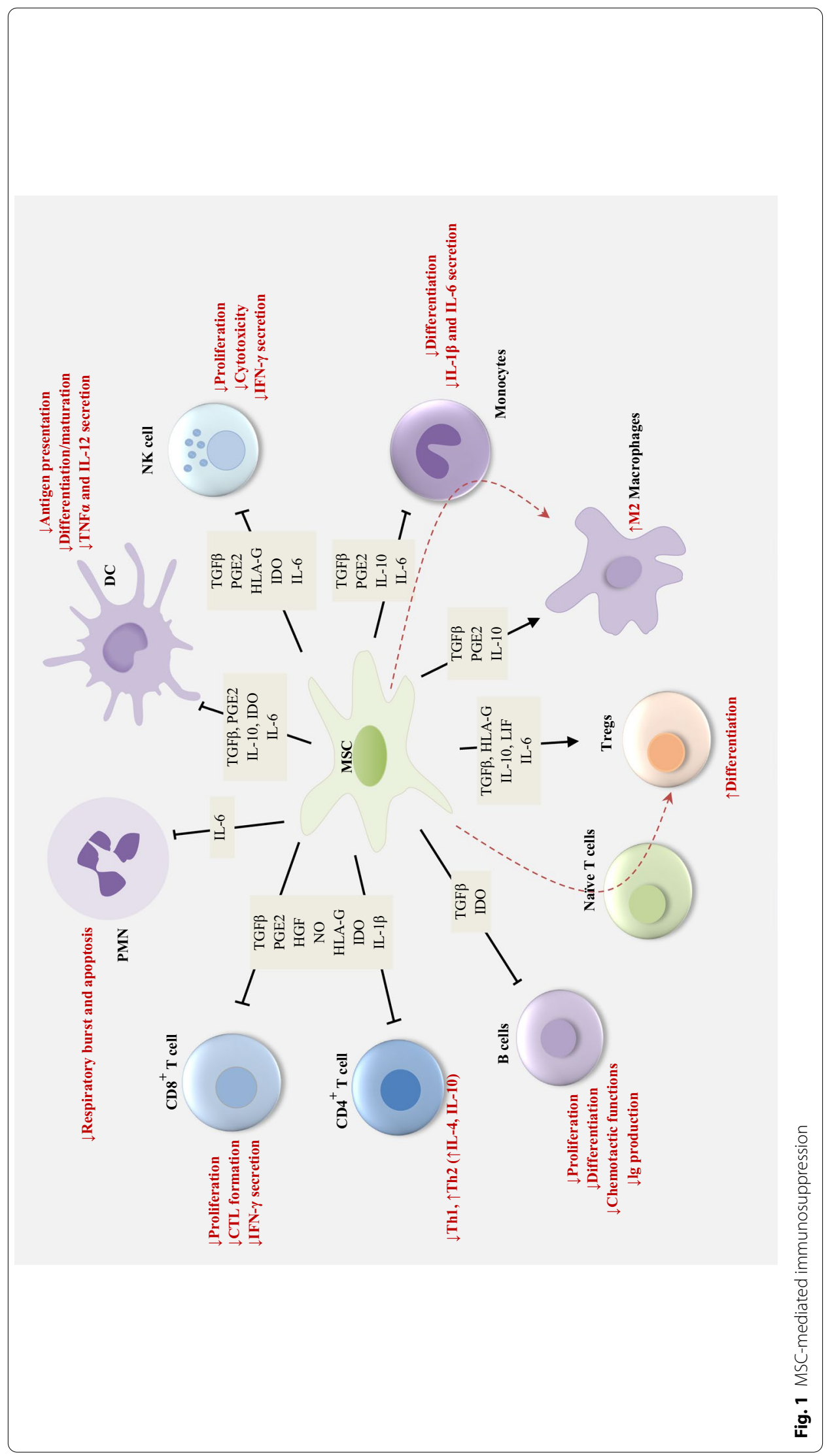


and nature killer (NK) cell activity [95, 96]. IDO is involved in the maturation of T helper cells into FOXP3-positive regulatory $\mathrm{T}$ cells that can inhibit effector $\mathrm{T}$ cell responses and thus reduce anti-tumor immunity [97, 98]. PGE2 induces secretion of anti-inflammatory cytokines like IL-10 and reduces the expression and synthesis of IFN- $\gamma$, TNF- $\alpha$ and IL-12 in macrophages and dendritic cells (DCs) [99]. PGE2 also diminishes the secretion of IL-4 and IFN- $\gamma$ in Th2 and Th1 cells, respectively, while promoting the proliferation of Treg cells [40]. Besides, MSCs induce skewing of the pro-inflammatory Th1 CD4 cells into an anti-inflammatory Th2 phenotype $[100,101]$. Reducing the IFN $\gamma$ production by T Helper 1 and enhancing IL-4 secretion via T Helper 2 minimizes anti-tumor immunity and the immune response. Monocyte differentiation is inhibited by MSC-secreted IL- 6 toward DCs, reducing the capability of DCs to stimumate T cells [102, 103]. Furthermore, MSC-secreted IL-6 led to the delay in apoptosis of neutrophils and lymphocytes $[104,105]$. NO is synthesized by inducible NO synthase (iNOS) through stimulation by inflammatory factors, such as IFN- $\gamma$, IL-1, and TNF- $\alpha[106,107]$ and then inhibition of the $\mathrm{T}$ cell functions [108].

Ultimately, recruitment of the inhibitory immune cells known as MDSCs (myeloidderived suppressor cells), is induced by MSCs through CCL2 signaling. This weakens the anti-cancer T cell activity [109]. Ucelli et al. found that MSCs prevent the proliferation of B cells by arresting the cell cycle [15]. B cell antibody production is reduced by MSCs, but this also inhibits their differentiation into plasma cells [110]. Galectin-9 is overexpressed by IFN $\gamma$-stimulated MSCs, attenuating antibody production and B cell proliferation [111]. Thus, MSCs show a robust inhibitory performance against adaptive immune cells and this capability is exploited by cancer cells.

NK cells are also suppressed by MSCs, mainly through IL-6 and PGE2 secretion. Furthermore, MSCs decrease NK cells' ability to express IFN $\gamma$, weakening their anti-cancer activity [112]. Moreover, MSCs attenuate the maturation of dendritic and other antigenpresenting cells (APCs) through PGE2 signaling [99]. Macrophage phagocytic capabilities are reduced when exposed to a conditioned medium of MSCs, thereby stimulating a pro-tumorigenic macrophage phenotype [113]. CD80/CD86 expression in APCs is reduced by MSCs, thus downregulating $\mathrm{T}$ cell activation [103]. Furthermore, MSCderived PGE2 and IDO induce the skewing of macrophages toward the pro-tumorigenic M2 phenotype, leading to the higher immune-inhibitory IL-10 levels [114]. Moreover, co-culturing CD11b/Ly6G-positive neutrophils with MSCs leads to massive in vitro inhibition of T cells, which was found to increase the growth of breast carcinoma in vivo [115]. There are also other reports indicating that neutrophil activation is promoted in gastric cancer by MSC-derived IL-6 through the STAT3-ERK1/2 signal transduction pathway and that their polarization is induced toward a tumor-supportive phenotype [116]. These findings represent the MSCs' extensive immunosuppressive impact on effector immune cells, which ultimately supports the progression of the tumor.

The high IFN- $\gamma$ levels within the pro-inflammatory intra-tumor environment increase the expression of PDL1 on MSCs, in turn inhibiting $\mathrm{T}$ cell activation and attenuating the activity of anti-cancer $\mathrm{T}$ cells [117]. Furthermore, high levels of soluble PD-1 ligands are secreted by MSCs, effectively suppressing the impact of IL-2 on $\mathrm{T}$ cell activation. In parallel, AKT activation paths are inhibited by the soluble PD-L1 and PD-L2 secreted by MSCs, so T cell activation and proliferation are 
inhibited [118]. Besides the T cell inhibition that is mediated by PD-1 and PD-L1, it was recently found that MSCs' immunosuppressive performance is partly mediated through CTLA-4 that MSCs express several types of them [119].

\section{Angiogenesis promotion}

Fast maturation and expansion of the tumor vasculature is essential to satisfy the high requirement for nutrients and oxygen in primary metastatic sites and tumors [120]. Various studies indicate that tumor angiogenesis is promoted by MSCs that differentiate into pericytes or endothelial-like cells and then secrete proangiogenic factors, trophic factors, cytokines, plasminogen activators and growth factors [88, 121, 122]. MSCs release high levels of cytokines and angiogenesis-stimulating growth factors, including VEGF, $\beta$ FGF, FGF-2, PDGF, IL-8, IL-6, angiopoietin and TGF $\beta$, which promote tumor angiogenesis $[88,123,124]$. Moreover, MSC-derived VEGF production is enhanced by high TGF $\alpha$ levels by inducing PI3K and MAPK paths, in turn activating the paracrine and autocrine loops and stimulating pro-angiogenic factor secretion [125, 126]. VEGF expression can increase the recruitment and mobilization of MSCs into neovascularization sites, where MSCs are directly differentiated into vascular cells [51, 127]. Furthermore, MSCs secrete cytokines like angiopoietin-1 (Ang-1) and IL-6 in colorectal carcinoma, in turn stimulating cancer cells to secrete endothelin-1 (ET-1), which in turn activates ERK and AKT paths in tumor endothelial cells, resulting in tumor vessel formation and mobilization $[128,129]$. The secretion of VEGF by MSCs can be incremented by hypoxic conditions as the prevalent event in tumor tissues [130]. Hypoxia results in HIF-1 $\alpha$ overexpression downregulating p21 and p53 and upregulating BCL-2 in MSCs, thus, promoting their survival [131]. Pro-angiogenic factors, such as PDGF and VEGF, are secreted by these surviving MSCs, resulting in local tumor angiogenesis $[132,133]$. Furthermore, endothelial cell recruitment is stimulated by VEGF secretion from MSCs in a hypoxic environment, supporting systemic and local tumor angiogenesis [134]. Moreover, blood vessel integrity is enhanced by MSCs through the induction of junctional protein expression [135]. The expression of cell-to-cell junction proteins, such as occludin is enhanced by MSC-derived Ang-1 in endothelial cells, reducing blood vessel leakiness [135]. The angiogenic procedure is also directly enhanced by MSCs that have differentiated into endothelial cells, pericytes and smooth muscle cells [136]. It was reported that MSCs are capable of differentiating into smooth muscle cells, and therefore can support tumor blood vessel maturation [137]. Indeed, differentiated pericytes supporting blood vessel integrity are regarded as originating from MSCs [138, 139]. Endothelial markers were not expressed by rat MSCs incorporated into tumor vessel walls including NG2, PDGFR- $\beta$, and $\alpha$-SMA [122]. The various pericyte marker expression profiles of engrafted MSCs and their perivascular position indicates the function of these cells as pericytes. Numerous specific markers for pericyte differentiation are expressed in human MSCs cultured in conditioned media derived from a glioblastoma [140,141]. Owing to the MSCs' pro-angiogenic nature into the growing tumors, current investigations are focusing on blocking the MSCs' angiogenic activities to enhance the anti-angiogenic therapy. 


\section{Conversion of MSCs to cancer-associated fibroblasts}

Kalluri et al. indicated that MSCs are resting fibroblasts and cancer-associated fibroblasts (CAFs) can be derived from them [142]. MSC-tumor cell interactions further augment MSC differentiation into CAFs [88, 143, 144]. CAFs are abundant in most invasive tumors and mostly include cells expressing $\alpha$-SMA ( $\alpha$-smooth muscle actin) [145]. They promote angiogenesis and tumor growth through the secretion of SDF-1 (stromalcell derived factor 1) [146], which binds to their receptor, CXCR4 [147]. Fibroblastderived mediators and factors like $\alpha$-SMA, tenascin-C, fibroblast surface protein (FSP), CXCL12, IL-6, and CCL5 are extensively produced by MSCs [88]. Tumor growth can be stimulated by CAFs and TAFs through their involvement in angiogenesis and the secretion of tumor-stimulating growth factors. Tumor angiogenesis is strongly promoted by CAFs through the production of immunomodulatory and pro-angiogenic chemokines and cytokines like IL-4, IL-8, IL-6, TNF, CXCL12, TGF $\beta$ and VEGF [142]. Therefore, tumor vascularization is promoted by MSCs through multiple mechanisms related to induction of vasculogenic mimicry and endothelial cell proliferation.

\section{Epithelial-mesenchymal transition}

Epithelial-mesenchymal transition (EMT) is determined by downregulation of the epithelial cell-related proteins E-cadherin, ZO-1 and $\gamma$-catenin/plakoglobin. However, the mesenchymal proteins are upregulated, such as fibronectin, $\mathrm{N}$-cadherin, smooth muscle actin and vimentin $[148,149]$. Although EMT is needed for wound healing and organogenesis, it is also related to epithelial tumor development [150]. Evidence indicates that tumor invasiveness, drug resistance and tumor metastasis are promoted by aberrant EMT [151]. EMT is promoted by MSCs through the secretion of cytokines and growth factors, including HGF, PDGF, EGF and TGF $\beta$, which induce the expression of transcriptional regulators related to EMT, such as Slug, Snail, Zeb1 and Twist [152, 153]. MSCs improve colon cancer cells' metastatic capacity through the increased expression of EMT-related genes, such as ZEB2, ZEB1, Twist, Slug, and Snail, in a contact-reliant mode. The EMT-associated gene E-cadherin is considerably downregulated in this process [154]. In hepatocellular carcinoma, the exposure of MSCs to IFN $\gamma$ and TNF $\alpha$ leads to overexpression of TGF $\beta$, which in turn promotes EMT-associated functional alterations in cancer cells [155]. A metastatic phenotype is promoted by TGF $\beta$-stimulated MSCs in pancreatic cancer via the upregulation of Jagged-1, a key ligand of Notch signaling in tumor cells [156]. In turn, EMT is induced by activation of the Notch path increase a cancer stem cell (CSC) phenotype. Other works linking EMT with CSCs support these results [157]. The expressions of metastatic and EMT genes (SERPINE1, IL-6, and MMP-2) were induced in tumor cells by MSCs secreted leptin. Moreover, when coinjecting MCF7 breast cancer cells and transfected MSCs with leptin shRNA into SCID/ beige mice, a reduction in leptin levels in MSCs occurs, finally causing a decrease in the number of metastatic lesions and in the MCF7 tumor volume in the mouse livers and lungs [158]. There are also reports on another mechanism of tumor cell dissemination induced by MSCs in gastric cancer. MSCs recruited by gastric mucosal cells infected with Helicobacter pylori differentiated into gastric cells expressing epithelial biomarkers like TFF2 and KRT1-19. The gastric cancer CSC phenotype is promoted by such biomarkers accompanied by chronic inflammation contributing to metastatic and EMT 
features [159]. Furthermore, MSCs can also fuse with various tumor cells that represent all the classical features of EMT [158, 160-162].

\section{Correlating MSCs with CSCs}

Some evidence indicates that tumor metastasis is mediated by CSCs, which are probably involved in relapses following radiation therapy and chemotherapy [163]. Liu et al. found that a cellular hierarchy is formed by MSC and CSC populations where breast CSCs are regulated by MSCs expressing aldehyde dehydrogenase through cytokine loops including CXCL 7 and IL-6 [164]. When an interaction occurs between IL-6 secreted by CSCs and IL-6R/gp130 expressed on MSCs, MSCs express CXCL7 [164]. In turn, the secretion of some cytokines, including IL-8, IL-6, CXCL5, and CXCL6, from both MSCs and CSCs is induced by CXCL7 [164]. It was indicated that the invasive properties and proliferation of CSCs are promoted by these cytokines, and that IL-6 promotes MSCs homing to the tumor sites in mouse xenograft models [90, 164]. BMP6, BMP4 and BMP2 are expressed by carcinoma-associated MSCs (CA-MSCs). In vitro culture of CSCs with BMP2 mimicked the impact of CA-MSCs on CSCs, while in vivo and in vitro MSCpromoted tumor growth was partly suppressed after the BMP2 signaling pathway was inhibited. These findings reveal that MSCs can stimulate tumor progression by incrementing the cancer stem cell number via BMP expression [165].

\section{Tumor metastasis promotion}

Several investigations demonstrated the influence of MSCs on cancer cell invasion and migration, EMT, and the creation of secondary metastatic lesions [75, 166-168]. These impacts are partly due to various growth factors, chemokines, and cytokines secreted by MSCs. $\mathrm{C}-\mathrm{X}-\mathrm{C}$ and $\mathrm{C}-\mathrm{C}$ are among the chemokines that promote tumor cell migration to secondary sites [169-172]. Growth factors like TGF $\beta$, HGF, FGF and EGF enhance tumor cell invasiveness and induce EMT $[75,173,174]$ as well as extracellular matrix modulating factors like lysyl oxidase (LOX) [167, 175]. In breast carcinoma, CCL5 is secreted by tumor-residing MSCs [90]. There is also a close relationship between CCL5mediated invasion and the incremented activity of matrix metalloproteinase 9 (MMP9) [59]. Nevertheless, this improved metastatic capacity is reversed by injecting MSCs into separate places, even in close proximity [90]. In another study, it was indicated that breast cancer cell directional migration and elongation are induced by co-cultured MSCs in vitro. The TGF $\beta$ signaling pathway in MSCs mediates the overexpression of matrix metalloproteinases (MMPs), rho-associated kinase and focal adhesion kinase (FAK) in breast cancer cells [174]. E-cadherin is downregulated by MSCs in tumor cells through the activation of ADAM10 and inhibition of the epithelial-like tumor cell phenotype [176]. Therefore, this activity of MSC disrupts cell-cell contact, thus increasing cell migration capabilities and promoting metastasis $[176,177]$. Tumor cell migration to metastatic lesions is promoted through MSC secretion of chemoattractants, such as CXCL1, CCL5, CXCL5, CXCL8 and CXCL7 [90, 174]. Furthermore, it was reported that tumor-derived osteopontin (OPN), a multipotent chemoattractant, promotes the expression of CCL5 in MSCs, which leads to incremented metastasis [86, 178]. Moreover, it was reported that high levels of CXCL12 (SDF-1) are secreted by MSCs that regulate the migration and invasion of CXCR4-expressing tumor cells [179, 180]. Moreover, 
bone metastasis can be supported by MSCs through the creation of metastatic niches at the bone and contribution to cancer cell recruitment to the bone ECM. These capabilities are related to their robust adhesive activities, which are facilitated by their secretion of integrins and adhesive molecules [181]. In general, MSCs contribute to the numerous stages within the metastatic procedure and have proven vital at pre-metastatic and primary tumor sites. Other mechanisms, such as the regulation of CSCs, induction of EMT, and changing mesenchymal niches also contribute to tumor invasion and metastasis [182].

\section{Inhibiting the apoptosis in cancer cells}

Tumor progression is associated with hypoxia, inflammation and starvation. Culturing MSCs in vitro under hypoxic circumstances incremented cellular proliferation and enhanced the production of Oct- 4 and Rex-1. Thus, an increase in MSC stemness during hypoxia was concluded [183]. Additionally, under starved and hypoxic circumstances, MSCs can increase their survival rate through autophagy and the secretion of numerous pro-survival or anti-apoptotic factors, including VEGF, PDGF, FGF-2, brainderived neurotrophic factor (BDNF), SDF-1 $\alpha$, HGF, IGF-2, IGF-1, IGF binding protein-2 (IGFBP-2) and transforming growth factor- $\beta$ (TGF- $\beta$ ) [184-188]. These factors can inhibit tumor cell apoptosis and promote tumor proliferation, these features are not seen in MSCs under normal conditions. In addition to the mitogenic features of growth factors released by MSCs, VEGF and FGF-2 can also induce the expression of Bcl-2, prolonging survival and delaying apoptosis [189-191]. However, the expressions of FGF-2 and VEGF can be induced by indirect angiogenic factors [192]. Moreover, it was reported that SDF-1 $\alpha$ prevents chronic lymphocytic leukemia (CLL) cells' drug-induced apoptosis [193]. It was also indicated that the angiogenic and anti-apoptotic impacts of hypoxic conditioning are stimulated by MSCs-derived factors, such as VEGF, HGF, FGF-2 and IGF-1 [49, 187]. Although less information exists about the direct supportive impact of MSCs on tumor cells under hypoxic circumstances, we know about the supportive potential of MSC-secreted growth factors triggered by hypoxia in the tumor microenvironment from observations of their angiogenic and anti-apoptotic impact.

\section{MSCs promote drug resistance}

Cancer chemoresistance mechanisms are not only related to aberrant gene mutations and multidrug resistance proteins, but also to different factors and conditions within the tumor microenvironment [194]. Numerous studies indicated that MSC pro-tumorigenic activities are improved in response to tumor perturbation, explaining chemoresistance and cancer regrowth [73]. In chronic myeloid leukemia (CML), CXCL12 is secreted by MSCs, reducing caspase 3 activity in a CXCR4-dependent manner and attenuating cell death induced by imatinib [133]. It was reported that in chronic lymphoid leukemia (CLL), CLL cells are protected from the cytotoxic impacts of Forodesine by MSCs enhancing the RNA and protein expression in the tumor cells [195]. It was also revealed that MSCs increase resistance to treatment in solid tumors. For example, in neck and head carcinoma, chemoresistance to paclitaxel is induced by bone marrow-derived mesenchymal stem cells (BM-MSCs) through paracrine signaling of IGF, EGF, IL-6, IL-7 and IL-8 [196]. It was found that in ovarian cancer, cancer cells are protected from cell 
death-induced hyperthermic intraperitoneal chemotherapy by tumor-residing MSCs that activate the CXCL12-CXCR4 axis. The thermo-sensitivity of ovarian cancer cells can be restored through blockage of the CXCR4 axis [197]. IL-6 expression by MSCs is another mechanism supporting tumor resistance. IL-6 stimulates Bcl-2 and Bcl-XL synthesis in cancer cells, resulting in the prevention of apoptosis after cytotoxic therapy [198]. Polyunsaturated fatty acids are secreted by MSCs that are exposed to cisplatin, protecting tumor cells from drug cytotoxicity. However, the mechanism of this protection is not known [199]. That study also showed that chemoresistance can be induced by non-tumor-residing MSCs and that MSCs can be considered guarding cells that protect cells from cytotoxic agents.

Previously, we discussed the involvement of MSCs in metastasis through facilitating EMT. Cancer cells that have undergone EMT are regarded as cancer stem cells or tumor cells with CSC properties [157, 200]. The CSCs are an exclusive rare population of cells within tumors. They show resistance to numerous cytotoxic agents, partly owing to their low proliferative rate, high DNA repair mechanisms, and expression of membrane drug transporters [201, 202]. Here, we discuss the capability of MSCs to either transform into CSCs or to support their microenvironment. MSCs can differentiate into CSCs by specific methylation in the tumor suppressor genes, HIC1, and RasF1A. Then, CSCs increase the chemoresistance to cisplatin and the risk of tumor relapse followed by treatment cessation [203]. Simultaneously, a CSC niche is supported by MSCs, and this contributes to their capability to resist chemotherapy toxicity [204, 205]. In breast cancer, CSCs are regulated by MSCs via cytokines like CXCL-7 and IL-6, thus promoting cancer progression[164]. In colorectal cancer, IL-1 released by cancer cells leads to the secretion of PGE-2 by MSCs. Through autocrine effects, that PGE-2 induces the production of IL-8, IL-6 and CXCL1, and these factors promote the formation of CSCs [91]. After differentiating into CAFs, MSCs are able to preserve CSCs by secreting the Notch ligand Jagged-1 [156]. Moreover, cisplatin changes the phosphorylation of various tyrosine kinase enzymes in MSCs, such as c-Jun, WNK-1, STAT3 and p53 that these proteins increase MSC survival and synthesis of IL- 8 and IL- 6 by MSCs, enhancing tumor cell chemoresistance [206]. However, the exact mechanisms of reduced chemoresistance by MSCs have not been fully clarified.

It was indicated that a physiological response to chemotherapy agents occurs in MSCs and eventually decreases chemoresistance by increasing the CSC population. MSCs are recruited numerously to pancreatic cancer sites in response to gemcitabine therapy, and they localize close to the CSC niches to support them. CXCL10 synthesis significantly increases in gemcitabine-exposed MSCs and promotes the proliferation of CSCs that have surface overexpression of CXCR3, which is a CXCL10 receptor. Ultimately, all these events lead to increased chemoresistance and enhanced tumor growth [207].

\section{Suppressive impacts of MSCs on tumor growth}

Although the tumor-promoting features of MSCs are clear from several studies, numerous other studies indicated tumor-suppressive features [56]. It is thought that MSCs suppress tumor growth by inhibition of Wnt and AKT signaling [66-68], suppression of angiogenesis [71], promotion of inflammatory cell infiltration [208], and induction of cell cycle arrest and apoptosis $[70,193,209,210]$. It has been shown that IFN- $\beta$ is produced 
by adipose tissue-derived MSCs cultured at high cell density, which reduces MCF-7 cell growth [211]. Furthermore, TRAIL is expressed by MSCs cultured with tri-dimensional systems or primed with IFN- $\gamma$, which can increase cancer cell-specific apoptosis [212, 213].

\section{Regulating the cell cycle}

The expressions of cyclin A, cyclin D2, p27KIP1, and cyclin E can be induced by cytokines that are secreted by MSCs. Their action ultimately leads to the cell cycle arrest of cancer cells at the G1 phase [204, 210, 214, 215]. It was found that human stromal cells differentiated from adipose tissue (ADSC) and ADSC-conditioned cell culture medium can suppress tumor progression [210]. Furthermore, in the absence of apoptosis, ADSCconditioned cell culture medium promotes cancer cell necrosis after G1-phase arrest. Tumor growth was inhibited when ADSC infiltrates pancreatic adenocarcinoma [210]. Similarly, the co-culture of cancer cells with MSCs also leads to cell cycle arrest of tumor cells at the G1 phase [204]. Nevertheless, co-injection of cancer cells with MSCs into non-obese, diabetic-severe, combined immunodeficient mice yielded higher tumor cell growth than tumor cell injection alone. The exact mechanisms of cell cycle arrest of tumor cells by MSCs remain unknown.

\section{Inducing inflammatory infiltrates}

Although immune responses can be suppressed by MSCs, in vivo co-administration of cancer cells and MSCs led to the enhanced infiltration of granulocytes and monocytes compared to separate cancer cell or MSC injection. In the study of Ohlsson et al., a gelatin matrix containing rat colon cancer cells and/or MSCs was utilized and transplanted subcutaneously into rats to monitor outgrowth of the tumor and the resultant inflammatory response. Rat colon carcinoma was inhibited by MSCs [208]. Infiltrations of macrophages and granulocytes were much greater in rats co-injected with MSCs and cancer cells than in rats injected with cancer cells without MSCs. These findings indicate the pro-inflammatory properties of MSCs in this model. However, the expressions of MHC-class I and MHC-type II in MSCs were low or absent respectively. Indeed, studies revealed a much smaller enhancement of granulocyte and macrophage infiltration when MSCs alone were added to the gelatin [208].

\section{Stimulation of apoptosis of tumor cells and endothelial cells}

The suppressive impacts of MSCs on tumor cell growth have been shown in the absence of host immunosuppression conditions, by inducing cancer cells apoptosis and G0/ G1 cell cycle arrest. MSCs were found to promote p21 expression [210]. Furthermore, MSCs were found to have anti-cancer activity in SCID mice xenografted with disseminated non-Hodgkin's lymphoma [216]. A single injection of MSCs enhanced the survival of animals with high-grade lymphoma. A considerable stimulation of endothelial cell apoptosis was indicated in a direct co-culture of endothelial cells with MSCs, indicating that they can have the anti-angiogenic activity [216]. The results concurred with some other studies that demonstrate a robust anti-angiogenic property of MSCs in Kaposi's sarcomas with high vascularity $[66,71]$. Additionally, it was reported that human umbilical cord blood-derived MSCs can induce the apoptosis of xenograft cells and glioma 
cells through downregulation of the X-linked inhibitor of apoptosis protein (XIAP) by activating caspase 3 and caspase-9 [70, 209]. High-density cultures of MSCs were found leading to the overexpression of type I IFN, which causes cell death of MDR-MB-231, MCF-7 and breast cancer cells [211]. Furthermore, TRAIL can be expressed by MSCs cultured with tri-dimensional systems or primed with IFN- $\gamma$ that increases cancer cell apoptosis [211, 213].

\section{Regulation of cellular signaling}

Cell growth, migration, survival, metabolism and proliferation are controlled by WNT/ $\beta$-catenin and PI3K/AKT signal transduction pathways [217-222]. Numerous studies have shown the importance of AKT signaling for the survival, invasion and migration of tumor cells. The Wnt signaling pathway has also been involved in the development of the breast, colon, liver, ovary, stomach and skin cancer [223-231]. It was reported that intravenously injected MSCs can travel to tumor sites and significantly decrease tumor cell proliferation by inhibiting the AKT signaling pathway in a Kaposi's sarcoma model [66]. Also, PTEN was upregulated in glioma cells by human cord blood-derived stromal cells (hUCBDSCs) leading to the downregulation of AKT [209]. Furthermore, MSCs are able to inhibit the $\mathrm{WNT} / \beta$-catenin signaling path by the induced expression of DKK-1 [67-69]. The results show the downregulation of $\beta$-catenin by DKK-1 secreted from MSCs in human carcinoma cell lines (breast: MCF-7; hepatocellular: HepG2 and H7402; and hematopoietic: HL60 and K562). Inhibiting DKK-1 activity by utilizing RNAi or neutralizing anti-DKK-1 antibodies results in reduced inhibitory impacts of MSCs on tumor cell proliferation [67-69].

\section{The therapeutic potential of engineered MSCs as a Trojan horse in cancer}

The wide application of anti-cancer and anti-proliferation agents is restricted by their high toxicity or short biological half-life. Cell-based therapy has recently emerged as one of the solutions to these limitations. Because of their inherent migratory properties, MSCs have attracted considerable attention among different cell types. These properties could allow them to be used as delivery vectors for anti-cancer therapy [232, 233].

As mentioned throughout this paper, the exact function of MSCs in cancer settings is still debatable and controversial. To solve the problem of their duality effect on cancer cells, researchers are trying to engineer MSCs to convert them into indisputable therapeutic tools and serve as an anti-cancer Trojan horse [234]. It is possible to equip MSCs with various factors. They have typically been genetically engineered to express desirable cytokines, anti-angiogenic, pro-apoptotic, anti-proliferative agents that specifically target different cancers, but have also been used as carriers for anti-cancer drugs [234]. Furthermore, both tumor-promoting and tumor-suppressive behaviors have been observed for MSC-derived microRNA [235-237]. Thus, MSCs can also be engineered to express desired and specific anti-cancer miRNA. 
Several studies utilized genetically manipulated MSCs to deliver and express various anti-tumor agents, including type I interferon (IFN- $\alpha$ and IFN- $\beta$ ), CXCL1, IL-2, IL-12, cytokine deaminase, oncolytic virus, TRAIL and nanoparticles [238-249]. Alternatively, engineered MSCs can express particular enzymes, such as herpes simplex virus-thymidine kinase (HSV-TK) or cytosine deaminase, which can convert inactive systemically administrated prodrugs, such as ganciclovir and fluorouracil (5-FU), into active cytotoxic drugs, reducing potential and systemic toxicity by facilitating tumor-localized chemotherapeutic activity [250,251]. MSCs are utilized in prostate cancer to promote drug specificity by delivering inactive prodrugs that can be activated in the cancer site through tumor-specific enzymes, including prostate-specific membrane antigen (PSMA) or prostate-specific antigen (PSA) [252, 253]. Moreover, MSCs can be utilized for effective targeting of nanoparticle-based drug delivery systems [247]. Taken together, these various approaches show the power of MSCs as effective anti-cancer delivery systems that are defined by reduced systemic toxicity and enhanced cancer specificity. The immune response is improved against glioma by IL-2-overexpressing MSCs [245] and melanoma [254] and decrease metastasis and invasion from a subcutaneous models [255]. NK and T cells are activated by IL-12 and CXCL1 secreted by MSCs, leading to a substantial decrease in breast and lung tumors and melanoma [244, 246, 255-257]. Since genetically engineered MSCs can increase the local concentrations of TRAIL, IFN- $\alpha$ and IFN- $\beta$, their tumor-suppressive activities are more effective compared to their activities when utilized in a systematical therapy [238, 240, 242, 243]. It was also found that CSCs can be specifically targeted by TRAIL-expressing MSCs in lung carcinoma, reducing chemoresistance, tumor aggressiveness and relapse rates [239]. MSCs have also been modified to deliver conditional replicative oncolytic viruses for specific targeting and inhibition of cancer cells without impact on normal cells, thus reducing metastasis and tumor growth $[241,258,259]$. In general, genetically modified MSCs are considered a promising therapeutic tool.

MSC therapy has numerous potential drawbacks that probably limit the expected clinical benefit, including the non-effective local concentration of therapeutic agents within the cancer microenvironment and non-specific distribution throughout the organism [260]. Furthermore, their physiological differentiation into mesenchymal lineages may promote immunogenicity, induce tumorigenesis and reduce therapeutic potential [261]. To overcome these challenges, MSC-derived extracellular vesicles (EV) were prepared and used as a drug delivery vector to directly target the cancer cells. The tumor homing ability is maintained by these MSC-derived EVs [262] with similar immune-suppressive features to the original MSCs [263]. In this concern, it was found that miRNA, cytokines, proteins and adhesion molecules can be delivered by exosomes from BM-derived MSCs 
and thereby influencing cancer development. For instance, glioma tumor growth was reduced by injecting exosomes obtained from miR-146b expressing MSCs [264]. Moreover, glioma stem cell survival was decreased by MSC-derived exosomes expressing miR-124a, and the migration properties of osteosarcoma cells were reduced by miR143 -containing exosomes $[265,266]$. It was also reported that genes driving tumorigenesis can be silenced by MSC-derived EVs loaded with siRNA [267]. It is also possible to load MSC-derived EVs with cytotoxic chemotherapy agents, such as doxorubicin, paclitaxel or gemcitabine. Such EVs were found to suppress oral squamous cancer cell growth and decrease cell viability [268].

Nanovesicles formed from MSC-derived nanoghosts (NGs; i.e., the outer membrane of mesenchymal stem cells) provide another type of MSC-derived EVs that display the unique features of MSCs [269]. MSC adhesion receptors and molecules are mainly preserved in NGs, so they maintain the capability to home to tumors [207, 270]. It was reported that lung and prostate tumor growth is inhibited by NGs loaded with RNA [270]. Moreover, CXCR3 antagonist containing MSC-derived NGs increase the sensitivity of pancreatic tumor CSCs to therapy, enhancing chemotherapy efficacy and postponing cancer re-growth [207]. In general, the immunosuppressive and regenerative properties of MSCs represent their potential as therapeutic tools for different kinds of malignancy.

\section{Conclusions and perspective}

MSCs are still one of the most promising therapeutic tools in tissue engineering and regeneration, cancer, and wound healing. Different cell types can affect tumor growth. Tumor cells and MSCs interact in various ways, hence, the MSCs either suppressing or supporting cancer progression based on multiple factors. MSCs support tumor growth through various mechanisms, including promotion of drug resistance, pro-angiogenic function, promotion of metastasis through induction of EMT, CSC niche enrichment, and profound immunoinhibitory properties (Fig. 2). These activities are related to mesenchymal stem cells secreted factors that affect several hallmarks of cancer. Moreover, the timing of MSC entrance into the tumor site may be vital for determining how they impact tumor development.

The homing ability of MSCs makes them excellent candidates as drug delivery vectors for therapeutic agents. More studies on the tumor growth mechanisms of MSCs can increase the potential to use them in regenerative medicine through improvements in their preparation to ensure minimal side effects and little or no risk of tumor cell growth. To further develop current anti-cancer treatment strategies, a better comprehension of the specific molecular mechanisms underlying these pro-tumorigenic activities is critical. Attenuation of MSC recruitment into tumor sites and inhibition of their tumor-supportive activities will make it possible to enhance the therapeutic outcomes for cancer patients, especially with the integration of other anticancer approaches, such as immunotherapy. Genetically modified MSCs possess great potential to specifically target tumor cells with minimal adverse effects and systemic toxicity. 


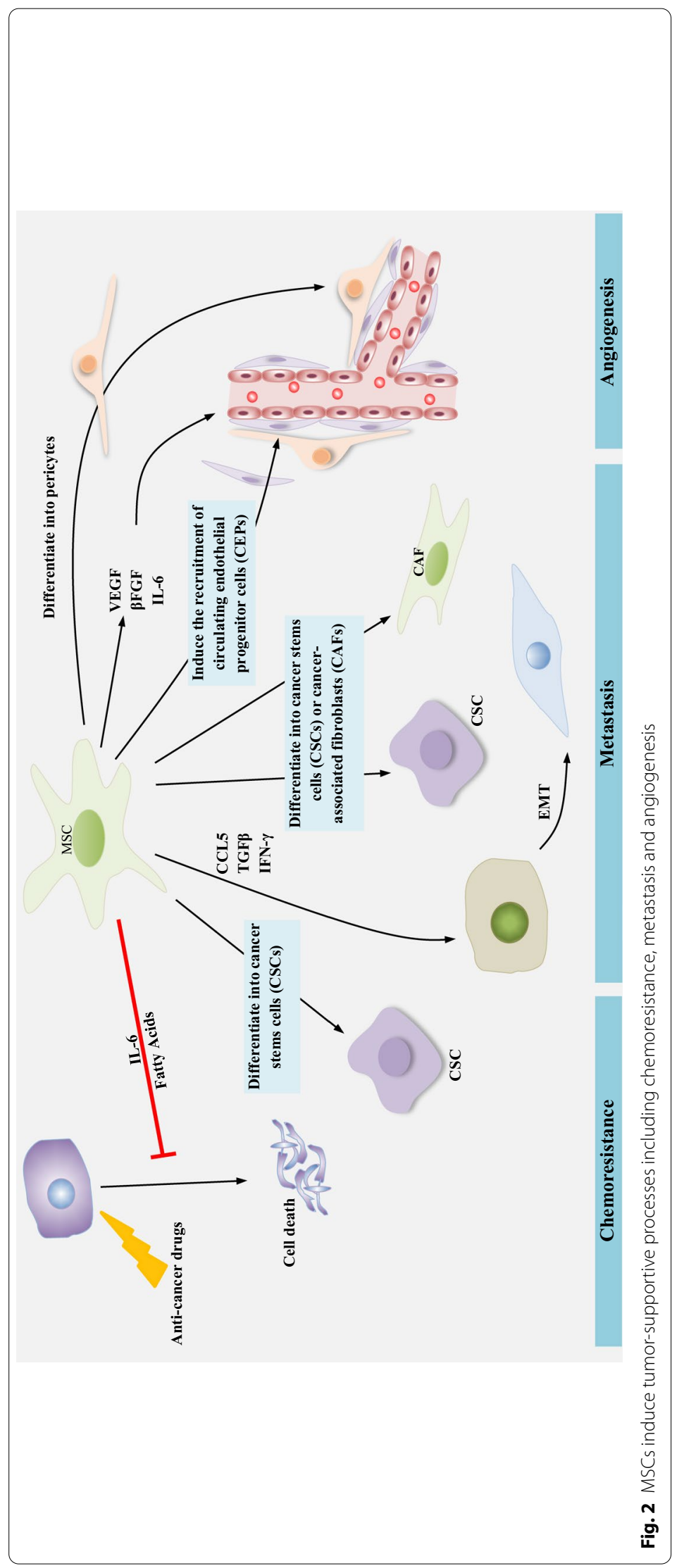




\section{Abbreviations}

a-SMA: $a$-Smooth muscle actin; Ang-1: Angiopoietin-1; APC: Antigen-presenting cell; BDNF: Brain-derived neurotrophic factor; CAF: Cancer-related fibroblast; CA-MSC: Carcinoma-associated MSCS; CLL: Chronic lymphocytic leukemia; CML: Chronic myeloid leukemia; CSC: Cancer stem cell; DC: Dendritic cell; ECM: Extracellular matrix; EMT: Epithelial-mesenchymal transition; ET-1: Endothelin-1; EV: Extracellular vesicle; FSP: Fibroblast surface protein; HLA: Human leukocyte antigen; HSV-TK: Herpes simplex virus-thymidine kinase; IDO: Indoleamine 2,3-dioxygenase; IGFBP-2: IGF binding protein-2; iNOS: Inducible NO synthase; ISCT: International society for cellular therapy; LOX: Lysyl oxidase; MDSC: Myeloid-derived suppressor cell; MMP-9: Matrix metalloproteinase 9; MSC: Mesenchymal stem cell; NK: Nature killer; NO: Nitric oxide; PD-1: Programmed death-1; PGE2: Prostaglandin 2; PI3K: Phosphoinositide 3-kinase; PSA: Prostate-specific antigen; PSMA: Prostate-specific membrane antigen; TGF- $\beta$ : Transforming growth factor- $\beta$; XIAP: X-linked inhibitor of apoptosis protein.

\section{Acknowledgements}

None.

\section{Authors' contributions}

Conception and design: WL, XZC; Collection and assembly of data: XZC, SZ and FJ; Manuscript writing: MC, YX, SZ and XC; Made critical revisions: WL, XZC, FJ and XC. All the authors reviewed and approved of the final manuscript.

\section{Funding}

This study was supported by the Nature Science Foundation of Zhejiang Province (LY18H060013 to WQL) and the Fundamental Research Program of Public Good in Zhejiang Province (LGF18H060006 to FJ, LGF20H060010 to XRC).

\section{Availability of data and materials \\ Not applicable.}

\section{Ethics approval and consent to participate}

Not applicable.

\section{Consent for publication}

Not applicable.

\section{Competing interests}

The authors declare no conflict of interest.

\section{Author details}

${ }^{1}$ Department of Orthopaedics, Zhoushan Hospital of Traditional Chinese Medicine Affiliated to Zhejiang Chinese Medical University, 355 Xinqiao Road, Dinghai District, Zhoushan 316000, Zhejiang, People's Republic of China. ${ }^{2}$ College of Medicine, Shaoxing University, Shaoxing 312000, Zhejiang, People's Republic of China. ${ }^{3}$ Department of Orthopaedics, Shaoxing People's Hospital, The First Affiliated Hospital of Shaoxing University, Shaoxing 312000, Zhejiang, People's Republic of China.

Received: 20 July 2020 Accepted: 27 December 2020

Published online: 20 January 2021

\section{References}

1. Zhang J, Liu Y, Yin W, Hu X. Adipose-derived stromal cells in regulation of hematopoiesis. Cell Mol Biol Lett. 2020;25(1):16.

2. Wei X, Yang X, Han ZP, Qu FF, Shao L, Shi YF. Mesenchymal stem cells: a new trend for cell therapy. Acta Pharmacol Sin. 2013;34(6):747-54

3. Salem HK, Thiemermann C. Mesenchymal stromal cells: current understanding and clinical status. Stem Cells. 2010;28(3):585-96.

4. Wang Y, Zhang D, Shen B, Zhang Y, Gu P. Stem/progenitor cells and biodegradable scaffolds in the treatment of retinal degenerative diseases. Curr Stem Cell Res Ther. 2017;13(3):160-73.

5. Cislo-Pakuluk A, Marycz K. A promising tool in retina regeneration: current perspectives and challenges when using mesenchymal progenitor stem cells in veterinary and human ophthalmological applications. Stem Cell Rev Rep. 2017;13(5):598-602.

6. Harris VK, Stark J, Vyshkina T, Blackshear L, Joo G, Stefanova V, et al. Phase I trial of intrathecal mesenchymal stem cell-derived neural progenitors in progressive multiple sclerosis. EBioMedicine. 2018;29:23-30.

7. Cui YB, Ma SS, Zhang CY, Cao W, Liu M, Li DP, et al. Human umbilical cord mesenchymal stem cells transplantation improves cognitive function in Alzheimer's disease mice by decreasing oxidative stress and promoting hippocampal neurogenesis. Behav Brain Res. 2017;320:291-301.

8. Kim HW, Lee HS, Kang JM, Bae SH, Kim C, Lee SH, et al. Dual effects of human placenta-derived neural cells on neuroprotection and the inhibition of neuroinflammation in a rodent model of Parkinson's disease. Cell Transplant. 2018;27(5):814-30.

9. Jamali F, Ma Hattab D, Amman J, Awidi A. Use of mesenchymal stem cells in Parkinson disease (PD). ClinicalTrials. gov. 2018. https://clinicaltrials.gov/ct2/show/NCT03684122.

10. Ahn J, Park EM, Kim BJ, Kim JS, Choi B, Lee SH, et al. Transplantation of human Wharton's jelly-derived mesenchymal stem cells highly expressing TGF $\beta$ receptors in a rabbit model of disc degeneration. Stem Cell Res Ther. 2015:6(1):190

11. Bonafede R, Mariotti R. ALS pathogenesis and therapeutic approaches: the role of mesenchymal stem cells and extracellular vesicles. Front Cell Neurosci. 2017;11:80. 
12. Evangelista AF, Vannier-Santos MA, de Assis Silva GS, Silva DN, Juiz PJL, Nonaka CKV, et al. Bone marrow-derived mesenchymal stem/stromal cells reverse the sensorial diabetic neuropathy via modulation of spinal neuroinflammatory cascades. J Neuroinflamm. 2018;15(1):189.

13. Chen XQ, Chen LL, Fan L, Fang J, Chen ZY, Li WW. Stem cells with FGF4-bFGF fused gene enhances the expression of bFGF and improves myocardial repair in rats. Biochem Biophys Res Commun. 2014;447(1):145-51.

14. Chen L, Liu G, Li W, Wu X. Chondrogenic differentiation of bone marrow-derived mesenchymal stem cells following transfection with Indian hedgehog and sonic hedgehog using a rotary cell culture system. Cell Mol Biol Lett. 2019;24(1):16.

15. Uccelli A, Moretta L, Pistoia V. Mesenchymal stem cells in health and disease. Nat Rev Immunol. 2008;8(9):726-36.

16. Liu ZJ, Zhuge Y, Velazquez OC. Trafficking and differentiation of mesenchymal stem cells. J Cell Biochem. 2009;106(6):984-91.

17. Haynesworth SE, Goshima J, Goldberg VM, Caplan Al. Characterization of cells with osteogenic potential from human marrow. Bone. 1992;13(1):81-8.

18. Pittenger MF, Mackay AM, Beck SC, Jaiswal RK, Douglas R, Mosca JD, et al. Multilineage potential of adult human mesenchymal stem cells. Science. 1999;284(5411):143-7.

19. Prockop DJ. Marrow stromal cells as stem cells for nonhematopoietic tissues. Science. 1997;276(5309):71-4.

20. Tropel P, Platet N, Platel J-C, Noël D, Albrieux M, Benabid A-L, et al. Functional neuronal differentiation of bone marrow-derived mesenchymal stem cells. Stem Cells. 2006;24(12):2868-76.

21. Phinney D, Isakova I. Plasticity and therapeutic potential of mesenchymal stem cells in the nervous system. Curr Pharm Des. 2005;11(10):1255-65.

22. Spees JL, Olson SD, Ylostalo J, Lynch PJ, Smith J, Perry A, et al. Differentiation, cell fusion, and nuclear fusion during ex vivo repair of epithelium by human adult stem cells from bone marrow stroma. Proc Natl Acad Sci USA. 2003;100(5):2397-402

23. Leuning DG, Beijer NRM, Du Fossé NA, Vermeulen S, Lievers E, Van Kooten C, et al. The cytokine secretion profile of mesenchymal stromal cells is determined by surface structure of the microenvironment. Sci Rep. 2018;8(1):7716.

24. Hwang NS, Zhang C, Hwang YS, Varghese S. Mesenchymal stem cell differentiation and roles in regenerative medicine. Wiley Interdiscip Rev Syst Biol Med. 2009;1(1):97-106.

25. Klingemann H, Matzilevich D, Marchand J. Mesenchymal stem cells - Sources and clinical applications. Transfus Med Hemother. 2008;35(4):272-7.

26. Fitzsimmons REB, Mazurek MS, Soos A, Simmons CA. Mesenchymal stromal/stem cells in regenerative medicine and tissue engineering. Stem Cells Int. 2018;2018:8031718.

27. DiMarino AM, Caplan Al, Bonfield TL. Mesenchymal stem cells in tissue repair. Front Immunol. 2013;4:201.

28. Rankin SM. Impact of bone marrow on respiratory disease. Curr Opin Pharmacol. 2008;8(3):236-41.

29. Wang CM. New family of zero-current-switching PWM converters using a new zero-current-switching PWM auxiliary circuit. IEEE Trans Ind Electron. 2006;53(3):768-77.

30. Yang C, Tang D. Patient-specific carotid plaque progression simulation. C Model Eng Sci. 2000;1 (2):119-31.

31. Deng J, Zou ZM, Zhou TL, Su YP, Ai GP, Wang JP, et al. Bone marrow mesenchymal stem cells can be mobilized into peripheral blood by G-CSF in vivo and integrate into traumatically injured cerebral tissue. Neurol Sci. 2011;32(4):641-51.

32. Marycz K, Mierzejewska K, Śmieszek A, Suszynska E, Malicka I, Kucia M, et al. Endurance exercise mobilizes developmentally early stem cells into peripheral blood and increases their number in bone marrow: implications for tissue regeneration. Stem Cells Int. 2016;2016:5756901.

33. Colter DC, Sekiya I, Prockop DJ. Identification of a subpopulation of rapidly self-renewing and multipotential adult stem cells in colonies of human marrow stromal cells. Proc Natl Acad Sci USA. 2001;98(14):7841-5.

34. Kuznetsov SA, Krebsbach PH, Satomura K, Kerr J, Riminucci M, Benayahu D, et al. Single-colony derived strains of human marrow stromal fibroblasts form bone after transplantation in vivo. J Bone Miner Res. 1997;12(9):1335-47.

35. Werts ED, DeGowin RL, Knapp SK, Gibson DP. Characterization of marrow stromal (fibroblastoid) cells and their association with erythropoiesis. Exp Hematol. 1980;8(4):423-33.

36. Dominici M, Le Blanc K, Mueller I, Slaper-Cortenbach I, Marini FC, Krause DS, et al. Minimal criteria for defining multipotent mesenchymal stromal cells. The International Society for Cellular Therapy position statement. Cytotherapy. 2006;8(4):315-7.

37. Nombela-Arrieta C, Ritz J, Silberstein LE. The elusive nature and function of mesenchymal stem cells. Nat Rev Mol Cell Biol. 2011;12(2):126-31.

38. Han ZC, Du WJ, Han ZB, Liang L. New insights into the heterogeneity and functional diversity of human mesenchymal stem cells. Biomed Mater Eng. 2017:28(s1):S29-45.

39. Pevsner-Fischer M, Levin S, Zipori D. The origins of mesenchymal stromal cell heterogeneity. Stem Cell Rev Rep. 2011;7(3):560-8.

40. Sharma RR, Pollock K, Hubel A, McKenna D. Mesenchymal stem or stromal cells: a review of clinical applications and manufacturing practices. Transfusion. 2014;54(5):1418-37.

41. Augello A, Tasso R, Negrini SM, Amateis A, Indiveri F, Cancedda R, et al. Bone marrow mesenchymal progenitor cells inhibit lymphocyte proliferation by activation of the programmed death 1 pathway. Eur J Immunol. 2005;35(5):1482-90.

42. Haddad R, Saldanha-Araujo F. Mechanisms of T-cell immunosuppression by mesenchymal stromal cells: What do we know so far? Biomed Res Int. 2014;2014:216806.

43. Najar M, Raicevic G, Kazan HF, de Bruyn C, Bron D, Toungouz M, et al. Immune-related antigens, surface molecules and regulatory factors in human-derived mesenchymal stromal cells: the expression and impact of inflammatory priming. Stem Cell Rev Rep. 2012;8(4):1188-98.

44. Kupcova SH. Proteomic techniques for characterisation of mesenchymal stem cell secretome. Biochimie. 2013;95(12):2196-211.

45. Sakaida I, Terai S, Yamamoto N, Aoyama K, Ishikawa T, Nishina H, et al. Transplantation of bone marrow cells reduces $\mathrm{CCl}_{4}$-induced liver fibrosis in mice. Hepatology. 2004;40(6):1304-11. 
46. Wang L, Wang X, Wang L, Chiu JD, Van De Ven G, Gaarde WA, et al. Hepatic vascular endothelial growth factor regulates recruitment of rat liver sinusoidal endothelial cell progenitor cells. Gastroenterology. 2012;143(6):1555-63.

47. Kim SU, Oh HJ, Wanless IR, Lee S, Han KH, Park YN. The Laennec staging system for histological sub-classification of cirrhosis is useful for stratification of prognosis in patients with liver cirrhosis. J Hepatol. 2012;57(3):556-63.

48. Wu Y, Zhao RCH, Tredget EE. Concise review: bone marrow-derived stem/progenitor cells in cutaneous repair and regeneration. Stem Cells. 2010;28(5):905-15.

49. Crisostomo PR, Wang Y, Markel TA, Wang M, Lahm T, Meldrum DR. Human mesenchymal stem cells stimulated by TNF-a, LPS, or hypoxia produce growth factors by an NFkB-but not JNK-dependent mechanism. Am J Physiol Cell Physiol. 2008:294(3):675-82.

50. Caplan Al, Dennis JE. Mesenchymal stem cells as trophic mediators. J Cell Biochem. 2006;98(5):1076-84.

51. Beckermann BM, Kallifatidis G, Groth A, Frommhold D, Apel A, Mattern J, et al. VEGF expression by mesenchymal stem cells contributes to angiogenesis in pancreatic carcinoma. Br J Cancer. 2008;99(4):622-31.

52. Block GJ, Ohkouchi S, Fung F, Frenkel J, Gregory C, Pochampally R, et al. Multipotent stromal cells are activated to reduce apoptosis in part by upregulation and secretion of stanniocalcin-1. Stem Cells. 2009;27(3):670-81.

53. Flier JS, Underhill LH, Dvorak HF. Tumors: wounds that do not heal. N Engl J Med. 1986;315(26):1650-9.

54. Kaneko Y, Tajiri N, Staples M, Reyes S, Lozano D, Sanberg PR, et al. Bone marrow-derived stem cell therapy for metastatic brain cancers. Cell Transplant. 2015;24(4):625-30.

55. Hanahan D, Weinberg RA. Hallmarks of cancer: the next generation. Cell. 2011;144(5):646-74

56. Klopp AH, Gupta A, Spaeth E, Andreeff M, Marini F. Concise review: dissecting a discrepancy in the literature: do mesenchymal stem cells support or suppress tumor growth? Stem Cells. 2011;29(1):11-9.

57. Zhang Y, Daquinag A, Traktuev DO, Amaya-Manzanares F, Simmons PJ, March KL, et al. White adipose tissue cells are recruited by experimental tumors and promote cancer progression in mouse models. Cancer Res. 2009;69(12):5259-66.

58. Jotzu C, Alt E, Welte G, Li J, Hennessy BT, Devarajan E, et al. Adipose tissue derived stem cells differentiate into carcinoma-associated fibroblast-like cells under the influence of tumor derived factors. Cell Oncol. 2011;34(1):55-67.

59. Pinilla S, Alt E, Abdul Khalek FJ, Jotzu C, Muehlberg F, Beckmann C, et al. Tissue resident stem cells produce CCL5 under the influence of cancer cells and thereby promote breast cancer cell invasion. Cancer Lett. 2009;284(1):80-5.

60. Krohn A, Song YH, Muehlberg F, Droll L, Beckmann C, Alt E. CXCR4 receptor positive spheroid forming cells are responsible for tumor invasion in vitro. Cancer Lett. 2009;280(1):65-71.

61. Marycz K, Weiss C, Śmieszek A, Kornicka K. Evaluation of oxidative stress and mitophagy during adipogenic differentiation of adipose-derived stem cells isolated from equine metabolic syndrome (EMS) horses. Stem Cells Int. 2018:2018:5340756.

62. Silva LHA, Antunes MA, Dos Santos CC, Weiss DJ, Cruz FF, Rocco PRM. Strategies to improve the therapeutic effects of mesenchymal stromal cells in respiratory diseases. Stem Cell Res Ther. 2018;9(1):45.

63. Moya A, Larochette N, Paquet J, Deschepper M, Bensidhoum M, Izzo V, et al. Quiescence preconditioned human multipotent stromal cells adopt a metabolic profile favorable for enhanced survival under ischemia. Stem Cells. 2017:35(1):181-96.

64. Shinmura D, Togashi I, Miyoshi S, Nishiyama N, Hida N, Tsuji H, et al. Pretreatment of human mesenchymal stem cells with pioglitazone improved efficiency of cardiomyogenic transdifferentiation and cardiac function. Stem Cells. 2011;29(2):357-66

65. Sanchez CG, Penfornis P, Oskowitz AZ, Boonjindasup AG, Cai DZ, Dhule SS, et al. Activation of autophagy in mesenchymal stem cells provides tumor stromal support. Carcinogenesis. 2011;32(7):964-72.

66. Khakoo AY, Pati S, Anderson SA, Reid W, Elshal MF, Rovira II, et al. Human mesenchymal stem cells exert potent antitumorigenic effects in a model of Kaposi's sarcoma. J Exp Med. 2006;203(5):1235-47.

67. Qiao L, Xu Z, Zhao T, Zhao Z, Shi M, Zhao RC, et al. Suppression of tumorigenesis by human mesenchymal stem cells in a hepatoma model. Cell Res. 2008;18(4):500-7.

68. Qiao L, Xu Z, Zhao T, Ye L, Zhang X. Dkk-1 secreted by mesenchymal stem cells inhibits growth of breast cancer cells via depression of Wnt signalling. Cancer Lett. 2008;269(1):67-77.

69. Zhu Y, Sun Z, Han Q, Liao L, Wang J, Bian C, et al. Human mesenchymal stem cells inhibit cancer cell proliferation by secreting DKK-1. Leukemia. 2009;23(5):925-33.

70. Dasari VR, Velpula KK, Kaur K, Fassett D, Klopfenstein JD, Dinh DH, et al. Cord blood stem cell-mediated induction of apoptosis in glioma downregulates X-linked inhibitor of apoptosis protein (XIAP). PLoS ONE. 2010:5(7):e11813

71. Otsu K, Das S, Houser SD, Quadri SK, Bhattacharya S, Bhattacharya J. Concentration-dependent inhibition of angiogenesis by mesenchymal stem cells. Blood. 2009:113(18):4197-205.

72. Rustad KC, Gurtner GC. Mesenchymal stem cells home to sites of injury and inflammation. Adv Wound Care. 2012;1(4):147-52.

73. Houthuijzen JM, Daenen LGM, Roodhart JML, Voest EE. The role of mesenchymal stem cells in anti-cancer drug resistance and tumour progression. Br J Cancer. 2012;106(12):1901-6.

74. Kidd S, Spaeth E, Dembinski JL, Dietrich M, Watson K, Klopp A, et al. Direct evidence of mesenchymal stem cell tropism for tumor and wounding microenvironments using in vivo bioluminescent imaging. Stem Cells. 2009:27(10):2614-23.

75. Hill BS, Pelagalli A, Passaro N, Zannetti A. Tumor-Educated mesenchymal stem cells promote Pro-Metastatic phenotype. Oncotarget. 2017;8(42):73296-311

76. Ponte AL, Marais E, Gallay N, Langonné A, Delorme B, Hérault O, et al. The in vitro migration capacity of human bone marrow mesenchymal stem cells: comparison of chemokine and growth factor chemotactic activities. Stem Cells. 2007;25(7):1737-45.

77. De Becker A, Van Riet I. Homing and migration of mesenchymal stromal cells: how to improve the efficacy of cell therapy? World J Stem Cells. 2016;8(3):73-87.

78. Matsushita H, Vesely MD, Koboldt DC, Rickert CG, Uppaluri R, Magrini VJ, et al. Cancer exome analysis reveals a T-cell-dependent mechanism of cancer immunoediting. Nature. 2012;482(7385):400-4. 
79. Mantovani A, Schioppa T, Porta C, Allavena P, Sica A. Role of tumor-associated macrophages in tumor progression and invasion. Cancer Metastasis Rev. 2006;25(3):315-22.

80. Dwyer RM, Potter-Beirne SM, Harrington KA, Lowery AJ, Hennessy E, Murphy JM, et al. Monocyte chemotactic protein-1 secreted by primary breast tumors stimulates migration of mesenchymal stem cells. Clin Cancer Res. 2007;13(17):5020-7.

81. Condeelis J, Pollard JW. Macrophages: obligate partners for tumor cell migration, invasion, and metastasis. Cell. 2006;124(2):263-6.

82. Lamagna C, Aurrand-Lions M, Imhof BA. Dual role of macrophages in tumor growth and angiogenesis. J Leukoc Biol. 2006;80(4):705-13.

83. Coffelt $\mathrm{SB}$, Hughes R, Lewis $\mathrm{CE}$. Tumor-associated macrophages: effectors of angiogenesis and tumor progression. Biochim Biophys Acta Rev Cancer. 2009;1796(1):11-8.

84. Siveen KS, Kuttan G. Role of macrophages in tumour progression. Immunol Lett. 2009;123(2):97-102.

85. Bissell MJ, Radisky D. Putting tumours in context. Nat Rev Cancer. 2001;1(1):46-54.

86. Xu W, Bian Z, Fan Q, Li G, Tang T. Human mesenchymal stem cells (hMSCs) target osteosarcoma and promote its growth and pulmonary metastasis. Cancer Lett. 2009;281(1):32-41.

87. Zhu W, Xu W, Jiang R, Qian H, Chen M, Hu J, et al. Mesenchymal stem cells derived from bone marrow favor tumor cell growth in vivo. Exp Mol Pathol. 2006;80(3):267-74.

88. Spaeth EL, Dembinski JL, Sasser AK, Watson K, Klopp A, Hall B, et al. Mesenchymal stem cell transition to tumor-associated fibroblasts contributes to fibrovascular network expansion and tumor progression. PLOS ONE. 2009:4(4):e4992.

89. Djouad F, Plence P, Bony C, Tropel P, Apparailly F, Sany J, et al. Immunosuppressive effect of mesenchymal stem cells favors tumor growth in allogeneic animals. Blood. 2003;102(10):3837-44.

90. Karnoub AE, Dash AB, Vo AP, Sullivan A, Brooks MW, Bell GW, et al. Mesenchymal stem cells within tumour stroma promote breast cancer metastasis. Nature. 2007:449(7162):557-63.

91. Li HJ, Reinhardt F, Herschman HR, Weinberg RA. Cancer-stimulated mesenchymal stem cells create a carcinoma stem cell niche via prostaglandin E2 signaling. Cancer Discov. 2012;2(9):840-55.

92. Torisu H, Ono M, Kiryu H, Furue M, Ohmoto Y, Nakayama J, et al. Macrophage infiltration correlates with tumor stage and angiogenesis in human malignant melanoma: possible involvement of TNFa and IL-1a. Int J Cancer. 2000:85(2):182-8.

93. Poggi A, Varesano S, Zocchi MR. How to hit mesenchymal stromal cells and make the tumor microenvironment immunostimulant rather than immunosuppressive. Front Immunol. 2018;9:262.

94. Rivera-Cruz CM, Shearer JJ, Figueiredo Neto M, Figueiredo ML. The immunomodulatory effects of mesenchymal stem cell polarization within the tumor microenvironment niche. Stem Cells Int. 2017;2017:4015039.

95. Volarevic V, Al-Qahtani A, Arsenijevic N, Pajovic S, Lukic ML. Interleukin-1 receptor antagonist (IL-1Ra) and IL-1Ra producing mesenchymal stem cells as modulators of diabetogenesis. Autoimmunity. 2010;43(4):255-63.

96. Parekkadan B, Van Poll D, Suganuma K, Carter EA, Berthiaume F, Tilles AW, et al. Mesenchymal stem cell-derived molecules reverse fulminant hepatic failure. PLoS ONE. 2007;2(9):e941.

97. Fallarino F, Grohmann U, You S, McGrath BC, Cavener DR, Vacca C, et al. The combined effects of tryptophan starvation and tryptophan catabolites down-regulate $T$ cell receptor $\zeta$-chain and induce a regulatory phenotype in naive T cells. J Immunol. 2006;176(11):6752-61.

98. Ma OKF, Chan KH. Immunomodulation by mesenchymal stem cells: interplay between mesenchymal stem cells and regulatory lymphocytes. World J Stem Cells. 2016;8(9):268-78.

99. Spaggiari GM, Abdelrazik H, Becchetti F, Moretta L. MSCs inhibit monocyte-derived DC maturation and function by selectively interfering with the generation of immature DCs: central role of MSC-derived prostaglandin E2. Blood. 2009;113(26):6576-83.

100. Bai L, Lennon DP, Eaton V, Maier K, Caplan Al, Miller SD, et al. Human bone marrow-derived mesenchymal stem cells induce Th2-polarized immune response and promote endogenous repair in animal models of multiple sclerosis. Glia. 2009;57(11):1192-203.

101. Fiorina P, Jurewicz M, Augello A, Vergani A, Dada S, La Rosa S, et al. Immunomodulatory function of bone marrowderived mesenchymal stem cells in experimental autoimmune type 1 diabetes. J Immunol. 2009;183(2):993-1004

102. Djouad F, Charbonnier L-M, Bouffi C, Louis-Plence P, Bony C, Apparailly F, et al. Mesenchymal stem cells inhibit the differentiation of dendritic cells through an interleukin-6-dependent mechanism. Stem Cells. 2007;25(8):2025-32.

103. Jiang $X X$, Zhang $Y$, Liu B, Zhang $S X$, Wu Y, Yu XD, et al. Human mesenchymal stem cells inhibit differentiation and function of monocyte-derived dendritic cells. Blood. 2005;105(10):4120-6.

104. Ren G, Su J, Zhang L, Zhao X, Ling W, L'Huillie A, et al. Species variation in the mechanisms of mesenchymal stem cell-mediated immunosuppression. Stem Cells. 2009;27(8):1954-62.

105. Sato K, Ozaki K, Oh I, Meguro A, Hatanaka K, Nagai T, et al. Nitric oxide plays a critical role in suppression of T-cell proliferation by mesenchymal stem cells. Blood. 2007;109(1):228-34.

106. Green SJ, Scheller LF, Marletta MA, Seguin MC, Klotz FW, Slayter M, et al. Nitric oxide: cytokine-regulation of nitric oxide in host resistance to intracellular pathogens. Immunol Lett. 1994;43(1-2):87-94.

107. Ren G, Zhang L, Zhao X, Xu G, Zhang Y, Roberts Al, et al. Mesenchymal stem cell-mediated immunosuppression occurs via concerted action of chemokines and nitric oxide. Cell Stem Cell. 2008;2(2):141-50.

108. Mazzoni A, Bronte V, Visintin A, Spitzer JH, Apolloni E, Serafini P, et al. Myeloid suppressor lines inhibit T cell responses by an NO-dependent mechanism. J Immunol. 2002;168(2):689-95.

109. Lee HJ, Ko JH, Jeong HJ, Ko AY, Kim MK, Wee WR, et al. Mesenchymal stem/stromal cells protect against autoimmunity via CCL2-dependent recruitment of myeloid-derived suppressor cells. J Immunol. 2015;194(8):3634-45.

110. Asari S, Itakura S, Ferreri K, Liu CP, Kuroda Y, Kandeel F, et al. Mesenchymal stem cells suppress B-cell terminal differentiation. Exp Hematol. 2009;37(5):604-15

111. Ungerer C, Quade-Lyssy P, Radeke HH, Henschler R, Königs C, Köhl U, et al. Galectin-9 is a suppressor of T and B cells and predicts the immune modulatory potential of mesenchymal stromal cell preparations. Stem Cells Dev. 2014;23(7):755-66. 
112. Galland S, Vuille J, Martin P, Letovanec I, Caignard A, Fregni G, et al. Tumor-derived mesenchymal stem cells use distinct mechanisms to block the activity of natural killer cell subsets. Cell Rep. 2017;20(12):2891-905.

113. Chen B, Ni Y, Liu J, Zhang Y, Yan F. Bone marrow-derived mesenchymal stem cells exert diverse effects on different macrophage subsets. Stem Cells Int. 2018;2018:8348121.

114. Vasandan AB, Jahnavi S, Shashank C, Prasad P, Kumar A, Jyothi PS. Human mesenchymal stem cells program macrophage plasticity by altering their metabolic status via a PGE 2-dependent mechanism. Sci Rep. 2016;6:38308.

115. Hu X, Zhou Y, Dong K, Sun Z, Zhao D, Wang W, et al. Programming of the development of tumor-promoting neutrophils by mesenchymal stromal cells. Cell Physiol Biochem. 2014;33(6):1802-14.

116. Zhu Q, Zhang X, Zhang L, Li W, Wu H, Yuan X, et al. The IL-6-STAT3 axis mediates a reciprocal crosstalk between cancer-derived mesenchymal stem cells and neutrophils to synergistically prompt gastric cancer progression. Cell Death Dis. 2014;5(6):e1295.

117. Sheng $H$, Wang $Y$, Jin $Y$, Zhang $Q$, Zhang $Y$, Wang L, et al. A critical role of IFNY in priming MSC-mediated suppression of T cell proliferation through up-regulation of B7-H1. Cell Res. 2008;18(8):846-57.

118. Davies LC, Heldring N, Kadri N, Le Blanc K. Mesenchymal stromal cell secretion of programmed death-1 ligands regulates T cell mediated immunosuppression. Stem Cells. 2017;35(3):766-76.

119. Gaber T, Schönbeck K, Hoff H, Tran CL, Strehl C, Lang A, et al. CTLA-4 mediates inhibitory function of mesenchymal stem/stromal cells. Int J Mol Sci. 2018;19(8):2312.

120. Carmeliet P, Jain RK. Angiogenesis in cancer and other diseases. Nature. 2000;407(6801):249-57.

121. Rajantie I, IImonen M, Alminaite A, Ozerdem U, Alitalo K, Salven P. Adult bone marrow-derived cells recruited during angiogenesis comprise precursors for periendothelial vascular mural cells. Blood. 2004;104(7):2084-6.

122. Bexell D, Gunnarsson S, Tormin A, Darabi A, Gisselsson D, Roybon L, et al. Bone marrow multipotent mesenchymal stroma cells act as pericyte-like migratory vehicles in experimental gliomas. Mol Ther. 2009:17(1):183-90.

123. Feng B, Chen L. Review of mesenchymal stem cells and tumors: executioner or coconspirator? Cancer Biother Radiopharm. 2009;24(6):717-21.

124. Du WJ, Chi Y, Yang ZX, Li ZJ, Cui JJ, Song BQ, et al. Heterogeneity of proangiogenic features in mesenchymal stem cells derived from bone marrow, adipose tissue, umbilical cord, and placenta. Stem Cell Res Ther. 2016;7(1):1-11.

125. Lee DC, Fenton SE, Berkowitz EA, Hissong MA. Transforming growth factor a: expression, regulation, and biological activities. Pharmacol Rev. 1995;47(1):51-85

126. Wang Y, Crisostomo PR, Wang M, Markel TA, Novotny NM, Meldrum DR. TGF-a increases human mesenchymal stem cell-secreted VEGF by MEK- and PI3-K-but not JNK- or ERK-dependent mechanisms. Am J Physiol Regul Integr Comp Physiol. 2008;295(4):1115-23.

127. Gyöngyösi M, Posa A, Pavo N, Hemetsberger R, Kvakan H, Steiner-Böker S, et al. Differential effect of ischaemic preconditioning on mobilisation and recruitment of haematopoietic and mesenchymal stem cells in porcine myocardial ischaemia-reperfusion. Thromb Haemost. 2010;104(2):376-84.

128. Huang WH, Chang MC, Tsai KS, Hung MC, Chen HL, Hung SC. Mesenchymal stem cells promote growth and angiogenesis of tumors in mice. Oncogene. 2013;32(37):4343-54.

129. O'Malley G, Heijltjes M, Houston AM, Rani S, Ritter T, Egan LJ, et al. Mesenchymal stromal cells (MSCs) and colorectal cancer-a troublesome twosome for the anti-tumour immune response? Oncotarget. 2016;7(37):60752-74.

130. Potier E, Ferreira E, Andriamanalijaona R, Pujol JP, Oudina K, Logeart-Avramoglou D, et al. Hypoxia affects mesenchymal stromal cell osteogenic differentiation and angiogenic factor expression. Bone. 2007:40(4):1078-87.

131. Lv B, Li F, Fang J, Xu L, Sun C, Han J, et al. Hypoxia inducible factor 1a promotes survival of mesenchymal stem cells under hypoxia. Am J Transl Res. 2017;9(3):1521-9.

132. Papaccio F, Paino F, Regad T, Papaccio G, Desiderio V, Tirino V. Concise review: cancer cells, cancer stem cells, and mesenchymal stem cells: influence in cancer development. Stem Cells Transl Med. 2017;6(12):2115-25.

133. Razban V, Lotfi AS, Soleimani M, Ahmadi H, Massumi M, Khajeh S, et al. HIF-1a overexpression induces angiogenesis in mesenchymal stem cells. Biores Open Access. 2012;1(4):174-83.

134. Fierro FA, O'Neal AJ, Beegle JR, Chávez MN, Peavy TR, Isseroff RR, et al. Hypoxic pre-conditioning increases the infiltration of endothelial cells into scaffolds for dermal regeneration pre-seeded with mesenchymal stem cells. Front Cell Dev Biol. 2015;3:68.

135. Zacharek A, Chen J, Cui X, Li A, Li Y, Roberts C, et al. Angiopoietin 1/Tie2 and VEGF/FIk1 induced by MSC treatment amplifies angiogenesis and vascular stabilization after stroke. J Cereb Blood Flow Metab. 2007;27(10):1684-91.

136. Birnbaum T, Roider J, Schankin CJ, Padovan CS, Schichor C, Goldbrunner R, et al. Malignant gliomas actively recruit bone marrow stromal cells by secreting angiogenic cytokines. J Neurooncol. 2007;83(3):241-7.

137. Gu W, Hong X, Le Bras A, Nowak WN, Bhaloo SI, Deng J, et al. Smooth muscle cells differentiated from mesenchymal stem cells are regulated by microRNAs and suitable for vascular tissue grafts. J Biol Chem. 2018;293(21):8089-102.

138. Caplan Al. All MSCs are pericytes? Cell Stem Cell. 2008;3(3):229-30.

139. Caplan AI. New MSC: MSCs as pericytes are sentinels and gatekeepers. J Orthop Res. 2017;35(6):1151-9.

140. Birnbaum T, Hildebrandt J, Nuebling G, Sostak P, Straube A. Glioblastoma-dependent differentiation and angiogenic potential of human mesenchymal stem cells in vitro. J Neurooncol. 2011;105(1):57-65.

141. Au P, Tam J, Fukumura D, Jain RK. Bone marrow derived mesenchymal stem cells facilitate engineering of longlasting functional vasculature. Blood. 2008;111(9):4551-8.

142. Kalluri R. The biology and function of fibroblasts in cancer. Nat Rev Cancer. 2016;16(9):582-98.

143. Ishihara S, Inman DR, Li WJ, Ponik SM, Keely PJ. Mechano-signal transduction in mesenchymal stem cells induces prosaposin secretion to drive the proliferation of breast cancer cells. Cancer Res. 2017;77(22):6179-89.

144. Barcellos-de-Souza P, Comito G, Pons-Segura C, Taddei ML, Gori V, Becherucci V, et al. Mesenchymal stem cells are recruited and activated into carcinoma-associated fibroblasts by prostate cancer microenvironment-derived TGFB1. Stem Cells. 2016;34(10):2536-47.

145. Sappino A-P, Skalli O, Jackson B, Schürch W, Gabbiani G. Smooth-muscle differentiation in stromal cells of malignant and non-malignant breast tissues. Int J Cancer. 1988;41(5):707-12. 
146. Orimo A, Gupta PB, Sgroi DC, Arenzana-Seisdedos F, Delaunay T, Naeem R, et al. Stromal fibroblasts present in invasive human breast carcinomas promote tumor growth and angiogenesis through elevated SDF-1/CXCL12 secretion. Cell. 2005;121(3):335-48.

147. Müller A, Homey B, Soto H, Ge N, Catron D, Buchanan ME, et al. Involvement of chemokine receptors in breast cancer metastasis. Nature. 2001;410(6824):50-6.

148. Grünert S, Jechlinger M, Beug H. Diverse cellular and molecular mechanisms contribute to epithelial plasticity and metastasis. Nat Rev Mol Cell Biol. 2003:4(8):657-65.

149. Jechlinger M, Grunert S, Tamir IH, Janda E, Lüdemann S, Waerner T, et al. Expression profiling of epithelial plasticity in tumor progression. Oncogene. 2003;22(46):7155-69.

150. Cannito S, Novo E, Di Bonzo LV, Busletta C, Colombatto S, Parola M. Epithelial-mesenchymal transition: from molecular mechanisms, redox regulation to implications in human health and disease. Antioxid Redox Signal. 2010;12(12):1383-430.

151. Polyak K, Weinberg RA. Transitions between epithelial and mesenchymal states: acquisition of malignant and stem cell traits. Nat Rev Cancer. 2009;9(4):265-73.

152. Martin FT, Dwyer RM, Kelly J, Khan S, Murphy JM, Curran C, et al. Potential role of mesenchymal stem cells (MSCs) in the breast tumour microenvironment: stimulation of epithelial to mesenchymal transition (EMT). Breast Cancer Res Treat. 2010;124(2):317-26.

153. Xue Z, Wu X, Chen X, Liu Y, Wang X, Wu K, et al. Mesenchymal stem cells promote epithelial to mesenchymal transition and metastasis in gastric cancer though paracrine cues and close physical contact. J Cell Biochem. 2015:116(4):618-27.

154. Chen D, Liu S, Ma H, Liang X, Ma H, Yan X, et al. Paracrine factors from adipose-mesenchymal stem cells enhance metastatic capacity through Wnt signaling pathway in a colon cancer cell co-culture model. Cancer Cell Int. 2015;15(1):42.

155. Jing Y, Han Z, Liu Y, Sun K, Zhang S, Jiang G, et al. Mesenchymal stem cells in inflammation microenvironment accelerates hepatocellular carcinoma metastasis by inducing epithelial-mesenchymal transition. PLoS ONE. 2012;7(8):e43272.

156. Kabashima-Niibe A, Higuchi H, Takaishi H, Masugi Y, Matsuzaki Y, Mabuchi Y, et al. Mesenchymal stem cells regulate epithelial-mesenchymal transition and tumor progression of pancreatic cancer cells. Cancer Sci. 2013:104(2):157-64.

157. Shibue T, Weinberg RA. EMT, CSCS, and drug resistance: the mechanistic link and clinical implications. Nat Rev Clin Oncol. 2017;14(10):611-29.

158. Strong AL, Ohlstein JF, Biagas BA, Rhodes LV, Pei DT, Tucker HA, et al. Leptin produced by obese adipose stromal/ stem cells enhances proliferation and metastasis of estrogen receptor positive breast cancers. Breast Cancer Res. 2015;17(1):112.

159. Houghton JM, Stoicov C, Nomura S, Rogers AB, Carlson J, Li H, et al. Gastric cancer originating from bone marrowderived cells. Science. 2004;306(5701):1568-71.

160. He X, Tsang TC, Pipes BL, Ablin RJ, Harris DT. A stem cell fusion model of carcinogenesis. J Exp Ther Oncol. 2005;5(2):101-9.

161. Rizvi AZ, Swain JR, Davies PS, Bailey AS, Decker AD, Willenbring $H$, et al. Bone marrow-derived cells fuse with normal and transformed intestinal stem cells. Proc Natl Acad Sci USA. 2006;103(16):6321-5.

162. Li H, Feng Z, Tsang TC, Tang T, Jia X, He X, et al. Fusion of HepG2 cells with mesenchymal stem cells increases cancer-associated and malignant properties: an in vivo metastasis model. Oncol Rep. 2014:32(2):539-47.

163. Kakarala M, Wicha MS. Implications of the cancer stem-cell hypothesis for breast cancer prevention and therapy. J Clin Oncol. 2008:26(17):2813-20.

164. Liu S, Ginestier C, Ou SJ, Clouthier SG, Patel SH, Monville F, et al. Breast cancer stem cells are regulated by mesenchymal stem cells through cytokine networks. Cancer Res. 2011;71(2):614-24.

165. McLean K, Gong Y, Choi Y, Deng N, Yang K, Bai S, et al. Human ovarian carcinoma-associated mesenchymal stem cells regulate cancer stem cells and tumorigenesis via altered BMP production. J Clin Invest. 2011;121(8):3206-19.

166. Fregni G, Quinodoz M, Möller E, Vuille J, Galland S, Fusco C, et al. Reciprocal modulation of mesenchymal stem cells and tumor cells promotes lung cancer metastasis. EBioMedicine. 2018;29:128-45.

167. El-Haibi CP, Bell GW, Zhang J, Collmann AY, Wood D, Scherber CM, et al. Critical role for lysyl oxidase in mesenchymal stem cell-driven breast cancer malignancy. Proc Natl Acad Sci USA. 2012;109(43):17460-5.

168. Zhang X, Hu F, Li G, Li G, Yang X, Liu L, et al. Human colorectal cancer-derived mesenchymal stem cells promote colorectal cancer progression through IL-6/JAK2/STAT3 signaling. Cell Death Dis. 2018;9(2):25.

169. Sarvaiya PJ, Guo D, Ulasov I, Gabikian P, Lesniak MS. Chemokines in tumor progression and metastasis. Oncotarget. 2013:4(12):2171-85

170. Yu PF, Huang Y, Han YY, Lin LY, Sun WH, Rabson AB, et al. TNFa-activated mesenchymal stromal cells promote breast cancer metastasis by recruiting CXCR2+ neutrophils. Oncogene. 2017;36(4):482-90.

171. Swamydas M, Ricci K, Rego SL, Dréau D. Mesenchymal stem cell-derived CCL-9 and CCL-5 promote mammary tumor cell invasion and the activation of matrix metalloproteinases. Cell Adhes Migr. 2013;7(3):315-24.

172. Halpern JL, Kilbarger A, Lynch CC. Mesenchymal stem cells promote mammary cancer cell migration in vitro via the CXCR2 receptor. Cancer Lett. 2011;308(1):91-9.

173. Berger L, Shamai Y, Skorecki KL, Tzukerman M. Tumor specific recruitment and reprogramming of mesenchymal stem cells in tumorigenesis. Stem Cells. 2016;34(4):1011-26.

174. McAndrews KM, McGrail DJ, Ravikumar N, Dawson MR. Mesenchymal stem cells induce directional migration of invasive breast cancer cells through TGF- $\beta$. Sci Rep. 2015;5:16941.

175. Thomas C, Karnoub AE. Lysyl oxidase at the crossroads of mesenchymal stem cells and epithelial-mesenchymal transition. Oncotarget. 2013:4(3):376-7.

176. Dittmer A, Hohlfeld K, Lützkendorf J, Müller LP, Dittmer J. Human mesenchymal stem cells induce E-cadherin degradation in breast carcinoma spheroids by activating ADAM10. Cell Mol Life Sci. 2009;66(18):3053-65. 
177. Klopp AH, Lacerda L, Gupta A, Debeb BG, Solley T, Li L, et al. Mesenchymal stem cells promote mammosphere formation and decrease E-cadherin in normal and malignant breast cells. PLoS ONE. 2010;5(8):e12180.

178. Mi Z, Bhattacharya SD, Kim VM, Guo H, Talbotq LJ, Kuo PC. Osteopontin promotes CCL5-mesenchymal stromal cell-mediated breast cancer metastasis. Carcinogenesis. 2011;32(4):477-87.

179. Eckert F, Schilbach K, Klumpp L, Bardoscia L, Sezgin EC, Schwab M, et al. Potential role of CXCR4 targeting in the context of radiotherapy and immunotherapy of cancer. Front Immunol. 2018;9:3018.

180. Ma M, Ye JY, Deng R, Dee CM, Chan GCF. Mesenchymal stromal cells may enhance metastasis of neuroblastoma via SDF-1/CXCR4 and SDF-1/CXCR7 signaling. Cancer Lett. 2011;312(1):1-10.

181. Reagan MR, Rosen CJ. Navigating the bone marrow niche: translational insights and cancer-driven dysfunction. Nat Rev Rheumatol. 2016;12(3):154-68.

182. Yang X, Hou J, Han Z, Wang Y, Hao C, Wei L, et al. One cell, multiple roles: contribution of mesenchymal stem cells to tumor development in tumor microenvironment. Cell Biosci. 2013;3(1):5.

183. Berniakovich I, Giorgio M. Low oxygen tension maintains multipotency, whereas normoxia increases differentiation of mouse bone marrow stromal cells. Int J Mol Sci. 2013;14(1):2119-34.

184. Sanchez C, Oskowitz A, Pochampally RR. Epigenetic reprogramming of IGF1 and leptin genes by serum deprivation in multipotential mesenchymal stromal cells. Stem Cells. 2009;27(2):375-82.

185. Hung SC, Pochampally RR, Hsu SC, Sanchez CC, Chen SC, Spees J, et al. Short-term exposure of multipotent stromal cells to low oxygen increases their expression of CX3CR1 and CXCR4 and their engraftment in vivo. PLoS ONE. 2007;2(5):e416.

186. Hung S-C, Pochampally RR, Chen S-C, Hsu S-C, Prockop DJ. Angiogenic effects of human multipotent stromal cell conditioned medium activate the PI3K-Akt pathway in hypoxic endothelial cells to inhibit apoptosis, increase survival, and stimulate angiogenesis. Stem Cells. 2007;25(9):2363-70,

187. Efimenko A, Starostina E, Kalinina N, Stolzing A. Angiogenic properties of aged adipose derived mesenchymal stem cells after hypoxic conditioning. J Transl Med. 2011;9:10.

188. Park JB, Lee JS, Cho BP, Rhee KJ, Baik SK, Kim J, et al. Adipose tissue-derived mesenchymal stem cells cultured at high cell density express brain-derived neurotrophic factor and exert neuroprotective effects in a 6-hydroxydopamine rat model of Parkinson's disease. Genes Genom. 2014;37(2):213-21.

189. Dias S, Choy M, Alitalo K, Rafii S. Vascular endothelial growth factor (VEGF)-C signaling through FLT-4 (VEGFR-3) mediates leukemic cell proliferation, survival, and resistance to chemotherapy. Blood. 2002;99(6):2179-84.

190. Dias S, Shmelkov SV, Lam G, Rafii S. VEGF165 promotes survival of leukemic cells by Hsp90-mediated induction of BCl-2 expression and apoptosis inhibition. Blood. 2002;99(7):2532-40.

191. König A, Menzel T, Lynen S, Wrazel L, Rosén A, Al-Katib A, et al. Basic fibroblast growth factor (bFGF) upregulates the expression of bcl-2 in B cell chronic lymphocytic leukemia cell lines resulting in delaying apoptosis. Leukemia. 1997;11(2):258-65

192. Brogi E, WU T, Namiki A, Isner JM. Indirect angiogenic cytokines upregulate VEGF and bFGF gene expression in vascular smooth muscle cells, whereas hypoxia upregulates VEGF expression only. Circulation. 1994;90(2):649-52.

193. Burger JA, Tsukada N, Burger M, Zvaifler NJ, Dell'Aquila M, Kipps TJ. Blood-derived nurse-like cells protect chronic lymphocytic leukemia B cells from spontaneous apoptosis through stromal cell-derived factor-1. Blood. 2000;96(8):2655-63.

194. Katz OB, Shaked Y. Host effects contributing to cancer therapy resistance. Drug Resist Updat. 2015;19:33-42.

195. Balakrishnan K, Burger JA, Quiroga MP, Henneberg M, Ayres ML, Wierda WG, et al. Influence of bone marrow stromal microenvironment on forodesine-induced responses in CLL primary cells. Blood. 2010;116(7):1083-91.

196. Scherzed A, Hackenberg S, Froelich K, Kessler M, Koehler C, Hagen R, et al. BMSC enhance the survival of paclitaxel treated squamous cell carcinoma cells in vitro. Cancer Biol Ther. 2011;11(3):349-57.

197. Lis R, Touboul C, Mirshahi P, Ali F, Mathew S, Nolan DJ, et al. Tumor associated mesenchymal stem cells protects ovarian cancer cells from hyperthermia through CXCL12. Int J Cancer. 2011;128(3):715-25.

198. Dreuw A, Hermanns HM, Heise R, Joussen S, Rodríguez F, Marquardt Y, et al. Interleukin-6-type cytokines upregulate expression of multidrug resistance-associated proteins in NHEK and dermal fibroblasts. J Invest Dermatol. 2005;124(1):28-37.

199. Roodhart JML, Daenen LGM, Stigter ECA, Prins HJ, Gerrits J, Houthuijzen JM, et al. Mesenchymal stem cells induce resistance to chemotherapy through the release of platinum-induced fatty acids. Cancer Cell. 2011;20(3):370-83.

200. Mani SA, Guo W, Liao MJ, Eaton EN, Ayyanan A, Zhou AY, et al. The epithelial-mesenchymal transition generates cells with properties of stem cells. Cell. 2008:133(4):704-15.

201. Moitra K. Overcoming multidrug resistance in cancer stem cells. Biomed Res Int. 2015;2015:635745.

202. Steinbichler TB, Dudás J, Skvortsov S, Ganswindt U, Riechelmann H, Skvortsova II. Therapy resistance mediated by cancer stem cells. Semin Cancer Biol. 2018;53:156-67.

203. Teng IW, Hou PC, Der LK, Chu PY, Yeh KT, Jin VX, et al. Targeted methylation of two tumor suppressor genes is sufficient to transform mesenchymal stem cells into cancer stem/initiating cells. Cancer Res. 2011;71(13):4653-63.

204. Ramasamy R, Lam EWF, Soeiro I, Tisato V, Bonnet D, Dazzi F. Mesenchymal stem cells inhibit proliferation and apoptosis of tumor cells: impact on in vivo tumor growth. Leukemia. 2007;21 (2):304-10.

205. Melzer $\mathrm{C}$, von der Ohe J, Lehnert H, Ungefroren $H$, Hass R. Cancer stem cell niche models and contribution by mesenchymal stroma/stem cells. Mol Cancer. 2017;16(1):28.

206. Skolekova S, Matuskova M, Bohac M, Toro L, Demkova L, Gursky J, et al. Cisplatin-induced mesenchymal stromal cells-mediated mechanism contributing to decreased antitumor effect in breast cancer cells. Cell Commun Signal. 2016;14(1):4

207. Timaner M, Letko-Khait N, Kotsofruk R, Benguigui M, Beyar-Katz O, Rachman-Tzemah C, et al. Therapy-educated mesenchymal stem cells enrich for tumor-initiating cells. Cancer Res. 2018;78(5):1253-65.

208. Ohlsson LB, Varas L, Kjellman C, Edvardsen K, Lindvall M. Mesenchymal progenitor cell-mediated inhibition of tumor growth in vivo and in vitro in gelatin matrix. Exp Mol Pathol. 2003;75(3):248-55. 
209. Dasari VR, Kaur K, Velpula KK, Gujrati M, Fassett D, Klopfenstein J, et al. Upregulation of PTEN in glioma cells by cord blood mesenchymal stem cells inhibits migration via downregulation of the PI3K/Akt pathway. PLoS ONE. 2010;5(4):e10350.

210. Lu YR, Yuan Y, Wang XJ, Wei LL, Chen YN, Cong C, et al. The growth inhibitory effect of mesenchymal stem cells on tumor cells in vitro and in vivo. Cancer Biol Ther. 2008;7(2):245-51.

211. Ryu H, Oh JE, Rhee KJ, Baik SK, Kim J, Kang SJ, et al. Adipose tissue-derived mesenchymal stem cells cultured at high density express IFN- $\beta$ and suppress the growth of MCF-7 human breast cancer cells. Cancer Lett. 2014;352(2):220-7.

212. Du J, Zhou L, Chen X, Yan S, Ke M, Lu X, et al. IFN- - -primed human bone marrow mesenchymal stem cells induce tumor cell apoptosis in vitro via tumor necrosis factor-related apoptosis-inducing ligand. Int J Biochem Cell Biol. 2012:44(8):1305-14.

213. Madrigal M, Rao KS, Riordan NH. A review of therapeutic effects of mesenchymal stem cell secretions and induction of secretory modification by different culture methods. J Transl Med. 2014;12(1):260.

214. Glennie S, Soeiro I, Dyson PJ, Lam EWF, Dazzi F. Bone marrow mesenchymal stem cells induce division arrest anergy of activated T cells. Blood. 2005;105(7):2821-7.

215. Aggarwal S, Pittenger MF. Human mesenchymal stem cells modulate allogeneic immune cell responses. Blood. 2005;105(4):1815-22.

216. Secchiero P, Zorzet S, Tripodo C, Corallini F, Melloni E, Caruso L, et al. Human bone marrow mesenchymal stem cells display anti-cancer activity in SCID mice bearing disseminated non-Hodgkin's lymphoma xenografts. PLoS ONE. 2010;5(6):e11140.

217. Engelman JA, Luo J, Cantley LC. The evolution of phosphatidylinositol 3-kinases as regulators of growth and metabolism. Nat Rev Genet. 2006;7(8):606-19.

218. Cantley LC. The phosphoinositide 3-kinase pathway. Science. 2002;296(5573):1655-7.

219. Altomare DA, Khaled AR. Homeostasis and the importance for a balance between AKT/mTOR activity and intracellular signaling. Curr Med Chem. 2012;19(22):3748-62.

220. Croce JC, McClay DR. Evolution of the Wnt pathways. Methods Mol Biol. 2008;469:3-18.

221. Jiang BH, Liu LZ. Chapter 2 PI3K/PTEN signaling in angiogenesis and tumorigenesis. Adv Cancer Res. 2009;102:19-65.

222. Song MS, Salmena L, Pandolfi PP. The functions and regulation of the PTEN tumour suppressor. Nat Rev Mol Cell Biol. 2012;13(5):283-96.

223. Polakis P. Wnt signaling in cancer. Cold Spring Harb Perspect Biol. 2012;4(5):9.

224. Giles RH, Van Es JH, Clevers H. Caught up in a Wnt storm: Wnt signaling in cancer. Biochim Biophys Acta - Rev Cancer 2003:1653(1):1-24

225. Logan CY, Nusse R. The Wnt signaling pathway in development and disease. Annu Rev Cell Dev Biol. 2004:20:781-810

226. Monga SP. B-Catenin signaling and roles in liver homeostasis, injury, and tumorigenesis. Gastroenterology. 2015;148(7):1294-310.

227. Chiurillo MA. Role of the Wnt/ $\beta$-catenin pathway in gastric cancer: an in-depth literature review. World J Exp Med. 2015;5(2):84.

228. Chen G, Shukeir N, Potti A, Sircar K, Aprikian A, Goltzman D, et al. Up-regulation of Wnt-1 and $\beta$-catenin production in patients with advanced metastatic prostate carcinoma: potential pathogenetic and prognostic implications. Cancer. 2004;101(6):1345-56.

229. Gaspar C, Fodde R. APC dosage effects in tumorigenesis and stem cell differentiation. Int J Dev Biol. 2004:48(5-6):377-86.

230. King TD, Suto MJ, Li Y. The wnt/ß-catenin signaling pathway: a potential therapeutic target in the treatment of triple negative breast cancer. J Cell Biochem. 2012;113(1):13-8.

231. Roarty K, Rosen JM. Wnt and mammary stem cells: hormones cannot fly wingless. Curr Opin Pharmacol. 2010;10(6):643-9.

232. Nowakowski A, Walczak P, Lukomska B, Janowski M. Genetic engineering of mesenchymal stem cells to induce their migration and survival. Stem Cells Int. 2016;2016:4956063.

233. Nowakowski A, Walczak P, Janowski M, Lukomska B. Genetic engineering of mesenchymal stem cells for regenerative medicine. Stem Cells Dev. 2015;24(19):2219-24.

234. Nowakowski A, Drela K, Rozycka J, Janowski M, Lukomska B. Engineered mesenchymal stem cells as an anti-cancer Trojan horse. Stem Cells Dev. 2016;25(20):1513-31.

235. Shimono Y, Mukohyama J, Nakamura S, Minami H. MicroRNA regulation of human breast cancer stem cells. J Clin Med. 2015;5(1):2.

236. Chen Y, Gao DY, Huang L. In vivo delivery of miRNAs for cancer therapy: challenges and strategies. Adv Drug Deliv Rev. 2015;81:128-41.

237. Gandhi NS, Tekade RK, Chougule MB. Nanocarrier mediated delivery of siRNA/miRNA in combination with chemotherapeutic agents for cancer therapy: current progress and advances. J Control Release. 2014;194:238-56.

238. Studeny M, Marini FC, Dembinski JL, Zompetta C, Cabreira-Hansen M, Bekele BN, et al. Mesenchymal stem cells: potential precursors for tumor stroma and targeted-delivery vehicles for anticancer agents. J Natl Cancer Inst. 2004;96(21):1593-603

239. Loebinger MR, Eddaoudi A, Davies D, Janes SM. Mesenchymal stem cell delivery of TRAlL can eliminate metastatic cancer. Cancer Res. 2009;69(10):4134-42.

240. Nakamizo A, Marini F, Amano T, Khan A, Studeny M, Gumin J, et al. Human bone marrow-derived mesenchymal stem cells in the treatment of gliomas. Cancer Res. 2005;65(8):3307-18.

241. Komarova S, Kawakami Y, Stoff-Khalili MA, Curiel DT, Pereboeva L. Mesenchymal progenitor cells as cellular vehicles for delivery of oncolytic adenoviruses. Mol Cancer Ther. 2006;5(3):755-66.

242. Ren C, Kumar S, Chanda D, Chen J, Mountz JD, Ponnazhagan S. Therapeutic potential of mesenchymal stem cells producing interferon-a in a mouse melanoma lung metastasis model. Stem Cells. 2008;26(9):2332-8. 
243. Ren C, Kumar S, Chanda D, Kallman L, Chen J, Mountz JD, et al. Cancer gene therapy using mesenchymal stem cells expressing interferon- $\beta$ in a mouse prostate cancer lung metastasis model. Gene Ther. 2008;15(21):1446-53.

244. Chen XC, Wang R, Zhao X, Wei YQ, Hu M, Wang YS, et al. Prophylaxis against carcinogenesis in three kinds of unestablished tumor models via IL12-gene-engineered MSCs. Carcinogenesis. 2006;27(12):2434-41.

245. Nakamura K, Ito Y, Kawano Y, Kurozumi K, Kobune M, Tsuda H, et al. Antitumor effect of genetically engineered mesenchymal stem cells in a rat glioma model. Gene Ther. 2004;1 1(14):1155-64.

246. Gao P, Ding Q, Wu Z, Jiang H, Fang Z. Therapeutic potential of human mesenchymal stem cells producing IL-12 in a mouse xenograft model of renal cell carcinoma. Cancer Lett. 2010;290(2):157-66.

247. Li L, Guan Y, Liu H, Hao N, Liu T, Meng X, et al. Silica nanorattle-doxorubicin-anchored mesenchymal stem cells for tumor-tropic therapy. ACS Nano. 2011;5(9):7462-70.

248. Xiang H, Nguyen CB, Kelley SK, Dybdal N, Escandón E. Tissue distribution, stability, and pharmacokinetics of APO2 ligand/tumor necrosis factor-related apoptosis-inducing ligand in human colon carcinoma COLO205 tumorbearing nude mice. Drug Metab Dispos. 2004;32(11):1230-8.

249. Menon LG, Kelly K, Hong WY, Kim SK, Black PM, Carroll RS. Human bone marrow-derived mesenchymal stromal cells expressing S-TRAIL as a cellular delivery vehicle for human glioma therapy. Stem Cells. 2009;27(9):2320-30.

250. Kucerova L, Altanerova V, Matuskova M, Tyciakova S, Altaner C. Adipose tissue-derived human mesenchymal stem cells mediated prodrug cancer gene therapy. Cancer Res. 2007;67(13):6304-13.

251. Cavarretta IT, Altanerova V, Matuskova M, Kucerova L, Culig Z, Altaner C. Adipose tissue-derived mesenchymal stem cells expressing prodrug-converting enzyme inhibit human prostate tumor growth. Mol Ther 2010;18(1):223-31.

252. Levy O, Brennen WN, Han E, Rosen DM, Musabeyezu J, Safaee H, et al. A prodrug-doped cellular Trojan horse for the potential treatment of prostate cancer. Biomaterials. 2016;91:140-50.

253. Krueger TEG, Thorek DL, Denmeade SR, Isaacs JT, Brennen WN. Concise review: mesenchymal stem cell-based drug delivery: the good, the bad, the ugly, and the promise. Stem Cells Transl Med. 2018;7(9):651-63.

254. Stagg J, Lejeune L, Paquin A, Galipeau J. Marrow stromal cells for interleukin-2 delivery in cancer immunotherapy. Hum Gene Ther. 2004;15(6):597-608.

255. Chen $X$, Lin X, Zhao J, Shi W, Zhang H, Wang Y, et al. A tumor-selective biotherapy with prolonged impact on established metastases based on cytokine gene-engineered MSCs. Mol Ther. 2008;16(4):749-56.

256. Xin H, Kanehira M, Mizuguchi H, Hayakawa T, Kikuchi T, Nukiwa T, et al. Targeted delivery of CX3CL1 to multiple lung tumors by mesenchymal stem cells. Stem Cells. 2007;25(7):1618-26.

257. Eliopoulos N, Francois M, Boivin MN, Martineau D, Galipeau J. Neo-organoid of marrow mesenchymal stromal cells secreting interleukin-12 for breast cancer therapy. Cancer Res. 2008;68(12):4810-8.

258. Stoff-Khalili MA, Rivera AA, Mathis JM, Banerjee NS, Moon AS, Hess A, et al. Mesenchymal stem cells as a vehicle for targeted delivery of CRAds to lung metastases of breast carcinoma. Breast Cancer Res Treat. 2007;105(2):157-67.

259. Dembinski JL, Spaeth EL, Fueyo J, Gomez-Manzano C, Studeny M, Andreeff M, et al. Reduction of nontarget infection and systemic toxicity by targeted delivery of conditionally replicating viruses transported in mesenchymal stem cells. Cancer Gene Ther. 2010;17(4):289-97.

260. Shah K. Mesenchymal stem cells engineered for cancer therapy. Adv Drug Deliv Rev. 2012;64(8):739-48.

261. Levy O, Zhao W, Mortensen LJ, LeBlanc S, Tsang K, Fu M, et al. MRNA-engineered mesenchymal stem cells for targeted delivery of interleukin-10 to sites of inflammation. Blood. 2013;122(14):e23-32.

262. Kalimuthu S, Gangadaran P, Rajendran RL, Zhu L, Oh JM, Lee HW, et al. A new approach for loading anticancer drugs into mesenchymal stem cell-derived exosome mimetics for cancer therapy. Front Pharmacol. 2018;9:1116.

263. Chulpanova DS, Kitaeva KV, Tazetdinova LG, James V, Rizvanov AA, Solovyeva VV. Application of Mesenchymal stem cells for therapeutic agent delivery in anti-tumor treatment. Front Pharmacol. 2018;9:259.

264. Katakowski M, Buller B, Zheng X, LuY, Rogers T, Osobamiro O, et al. Exosomes from marrow stromal cells expressing miR-146b inhibit glioma growth. Cancer Lett. 2013;335(1):201-4.

265. Shimbo K, Miyaki S, Ishitobi H, Kato Y, Kubo T, Shimose S, et al. Exosome-formed synthetic microRNA-143 is transferred to osteosarcoma cells and inhibits their migration. Biochem Biophys Res Commun. 2014;445(2):381-7.

266. Lang FM, Hossain A, Gumin J, Momin EN, Shimizu Y, Ledbetter D, et al. Mesenchymal stem cells as natural biofactories for exosomes carrying miR-124a in the treatment of gliomas. Neuro Oncol. 2018;20(3):380-90.

267. Greco KA, Franzen CA, Foreman KE, Flanigan RC, Kuo PC, Gupta GN. PLK-1 silencing in bladder cancer by siRNA delivered with exosomes. Urology. 2016;91(241):e1-7.

268. Coccè V, Farronato D, Brini AT, Masia C, Giannì AB, Piovani G, et al. Drug loaded gingival mesenchymal stromal cells (GinPa-MSCs) inhibit in vitro proliferation of oral squamous cell carcinoma. Sci Rep. 2017;7(1):9376.

269. Toledano Furman NE, Lupu-Haber Y, Bronshtein T, Kaneti L, Letko N, Weinstein E, et al. Reconstructed stem cell nanoghosts: a natural tumor targeting platform. Nano Lett. 2013;13(7):3248-55.

270. Kaneti L, Bronshtein T, Malkah Dayan N, Kovregina I, Letko Khait N, Lupu-Haber Y, et al. Nanoghosts as a novel natural nonviral gene delivery platform safely targeting multiple cancers. Nano Lett. 2016;16(3):1574-82.

\section{Publisher's Note}

Springer Nature remains neutral with regard to jurisdictional claims in published maps and institutional affiliations. 